\title{
Database for Assessment Unit-Scale Analogs (Exclusive of the United States)
}

Open-File Report 2007-1404 


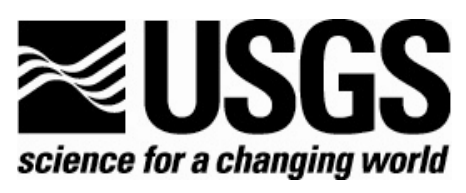

\section{Database for Assessment Unit-Scale Analogs (Exclusive of the United States)}

By Ronald R. Charpentier, T.R. Klett, and Emil D. Attanasi

Open-File Report 2007-1404

U.S. Department of the Interior U.S. Geological Survey 


\title{
U.S. Department of the Interior DIRK KEMPTHORNE, Secretary
}

\author{
U.S. Geological Survey \\ Mark D. Myers, Director
}

U.S. Geological Survey, Reston, Virginia 2008

For product and ordering information:

World Wide Web: http://www.usgs.gov/pubprod

Telephone: 1-888-ASK-USGS

For more information on the USGS - the Federal source for science about the Earth, its natural and living resources, natural hazards, and the environment: World Wide Web: http://www.usgs.gov

Telephone: 1-888-ASK-USGS

Suggested citation:

Charpentier, R.R., Klett, T.R., and Attanasi, E.D., 2008, Database for assessment unit-scale analogs (exclusive of the United States): U.S. Geological Survey Open-File Report 2007-1404, $61 \mathrm{p}$.

Any use of trade, product, or firm names is for descriptive purposes only and does not imply endorsement by the U.S. Government.

Although this report is in the public domain, permission must be secured from the individual copyright owners to reproduce any copyrighted material contained within this report. 


\section{Table of Contents}

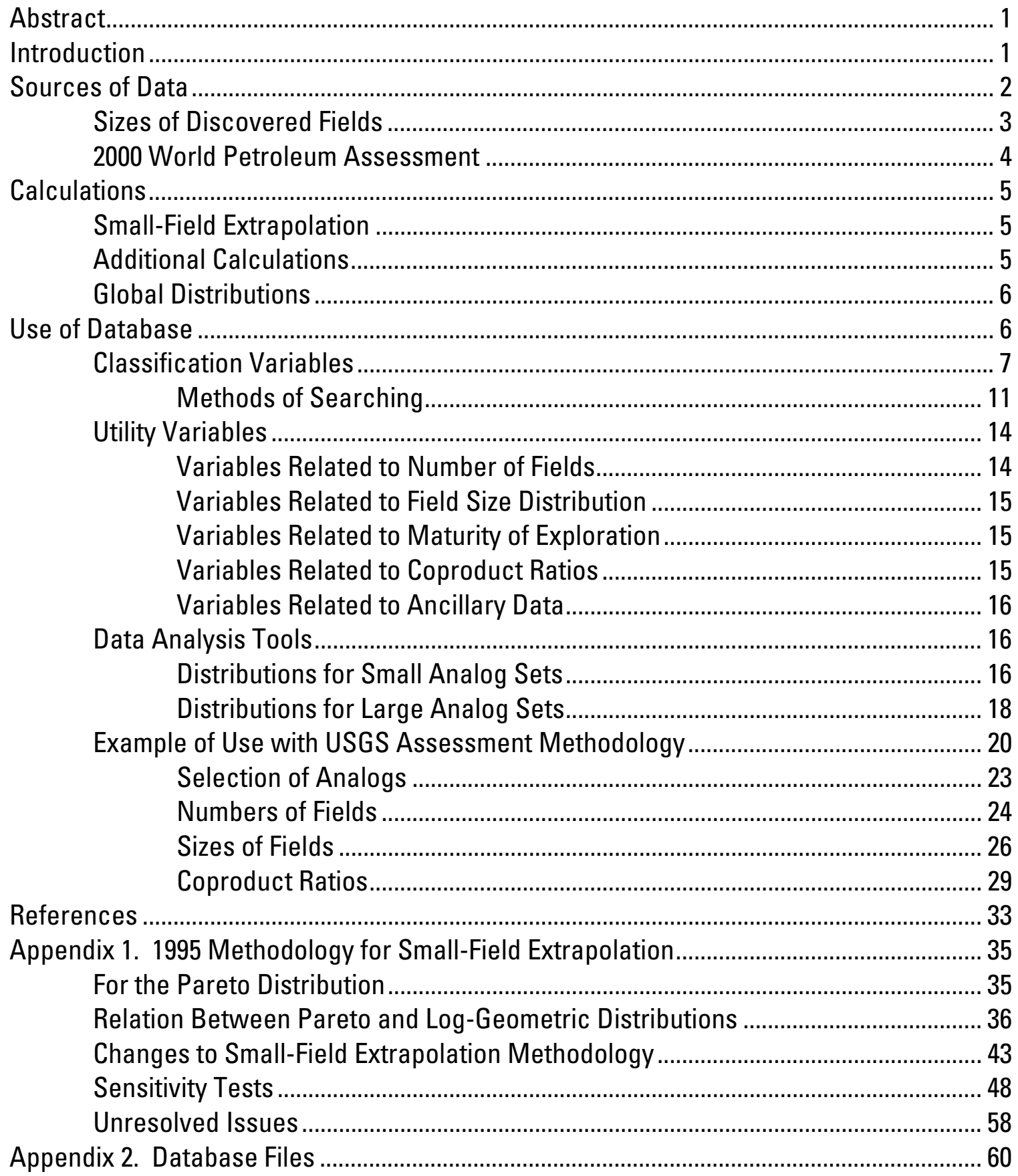




\section{Abstract}

This publication presents a database of geologic analogs useful for the assessment of undiscovered oil and gas resources. Particularly in frontier areas, where few oil and gas fields have been discovered, assessment methods such as discovery process models may not be usable. In such cases, comparison of the assessment area to geologically similar but more maturely explored areas may be more appropriate. This analog database consists of 246 assessment units, based on the U.S. Geological Survey 2000 World Petroleum Assessment. Besides geologic data to facilitate comparisons, the database includes data pertaining to numbers and sizes of oil and gas fields and the properties of their produced fluids.

\section{Introduction}

This publication presents a database of geologic analogs useful for the assessment of undiscovered oil and gas resources. Primary use of the database is to compare an immaturely explored area to a geologically analogous area that has been more maturely explored.

Particularly in cases of assessing undiscovered resources in immature areas, sufficient discovery history data may not be available for other methodologies, such as discovery process models, to be employed.

Each of the 246 analogs in the database is at the assessment unit (AU) scale and is based on the assessments of undiscovered resources in the U.S. Geological Survey (USGS) 2000 World Petroleum Assessment (U.S. Geological Survey World Energy Assessment Team, 2000, referred to as the "WPA 2000"). In that publication, an assessment unit was defined as "A mappable volume of rock within the total petroleum system that encompasses fields (discovered and undiscovered) which share similar geologic traits and socio-economic factors" (Klett and others, 2000). An AU is equivalent to a "play" or a group of related plays. The horizontal and vertical sizes of assessment units (their areal extent and the volume of rocks involved) can vary from one that covers the entire province to one covering only a small portion (exploration-trend scale). Because the WPA 2000 provided estimates only for selected provinces outside the United States, the database does not include any analogs from U.S. areas.

The methodology used in most USGS assessments relies on estimates of numbers and sizes of undiscovered accumulations. An accumulation may consist of an entire field or only that part of a field that is within a particular AU. (Note: in the WPA 2000, fields were not subdivided, except that pools were used in the Western Canada Sedimentary Basin). The term "accumulation" is used herein when referring to the USGS methodology and the term "fields" is used when referring to the analog database. Thus, the database provides information primarily on numbers and sizes of discovered and undiscovered fields and the geologic characteristics by which analogs may be chosen.

The files containing the database are included in two formats. A Microsoft Excel version (WorldAnalogs.xls) can be read by users of that software. This version includes several software tools, described below, to assist the user in selecting sets of analogs and in creating interpretive 
charts. An alternate version, for non-users of Microsoft Excel, is presented as eight tabdelimited files (WA_geology.tab, WA_oil.tab, WA_gas.tab, WA_BOE.tab, WA_oilbins.tab, WA_gasbins.tab, WA_BOEbins.tab, and WA_ancillary.tab). This version can be used with other spreadsheet programs, but does not include any software tools.

\section{Sources of Data}

The basic data for our analog database are drawn from three sources: (1) sizes and numbers of discovered fields are mostly from the IHS Energy, Inc. Exploration and Production database (IHS Energy, Inc., 2004); (2) sizes and numbers of Canadian pools are from the NRG Associates (1995) Significant Oil and Gas Pools of Canada Data Base; and (3) sizes and numbers of undiscovered fields are from the WPA 2000 (U.S. Geological Survey World Energy Assessment Team, 2000).

Only those oil and gas accumulations considered discovered in the WPA 2000 were counted as discovered in our analog database. For the most part, those accumulations were discovered before January 1, 1996, except for the Central Congo Turbidites AU 72030302, for which 24 discoveries from 1996 to 1999 were also included in the WPA 2000.

In all cases, the basic data are presented as counts or statistical expectations (mean estimates) in the standard USGS field-size classes, as listed in table 1. Accumulation sizes are based on the reported recoverable quantities (volumes of cumulative production plus reserves) according to the primary product (oil in oil accumulations, gas in gas accumulations) rather than a total volume of all products. Oil accumulations are differentiated from gas accumulations in that they have a gas to oil ratio (based on cumulative production plus reserves) of less than twenty thousand cubic feet per barrel. Where the analog database relates sizes in barrels of oil equivalent (BOE), an equivalency of one barrel of oil to six thousand cubic feet of natural gas was used ( $1 \mathrm{BOE}=1$ barrel of oil $=6,000$ cubic feet of gas).

Table 1. Standard USGS field-size class definitions

\begin{tabular}{rcc}
\hline $\begin{array}{c}\text { Size } \\
\text { Class }\end{array}$ & $\begin{array}{c}\text { Oil Field Size * } \\
\text { (Millions of barrels) }\end{array}$ & $\begin{array}{c}\text { Gas Field Size * } \\
\text { (Billions of cubic feet) }\end{array}$ \\
\hline 1 & 0.03125 to 0.0625 & 0.1875 to 0.375 \\
2 & 0.0625 to 0.125 & 0.375 to 0.75 \\
3 & 0.125 to 0.25 & 0.75 to 1.5 \\
4 & 0.25 to 0.5 & 1.5 to 3 \\
5 & 0.5 to 1 & 3 to 6 \\
6 & 1 to 2 & 6 to 12 \\
7 & 2 to 4 & 12 to 24 \\
8 & 4 to 8 & 24 to 48 \\
9 & 8 to 16 & 48 to 96 \\
10 & 16 to 32 & 96 to 192
\end{tabular}




\begin{tabular}{lcc}
11 & 32 to 64 & 192 to 384 \\
12 & 64 to 128 & 384 to 768 \\
13 & 128 to 256 & 768 to 1,536 \\
14 & 256 to 512 & 1,536 to 3,072 \\
15 & 512 to 1,024 & 3,072 to 6,144 \\
16 & 1,024 to 2,048 & 6,144 to 12,288 \\
17 & 2,048 to 4,096 & 12,288 to 24,576 \\
18 & 4,096 to 8,192 & 24,576 to 49,152 \\
19 & 8,192 to 16,384 & 49,152 to 98,304 \\
20 & 16,384 to 32,768 & 98,304 to 196,608 \\
21 & 32,768 to 65,536 & 196,608 to 393,216 \\
22 & 65,536 to 131,072 & 393,216 to 786,432 \\
23 & 131,072 to 262,144 & 786,432 to $1,572,864$ \\
\hline
\end{tabular}

${ }^{*}$ Accumulations of sizes exactly on a class boundary are counted in the higher class.

Because the original data were from proprietary databases, some appropriate modifications were made for the version of the file released to the public. The field sizes were binned to obscure their precise sizes, but the sizes of the largest discovered fields were rounded to 1.38 times the lower limit of their bin (see Appendix 1). There were nine AUs (10080101, 10090102, 10160101, 11500301, 38170103, 60220101, 60340102, 60900103, and 80470201) that only had one discovered field. For these, ancillary data were not reported, and the totals for known oil, gas, natural gas liquids, and total petroleum (Geology worksheet columns W, Y, AA, and $\mathrm{AC}$ ) are marked as "NA" (not available). None of the remaining data can thus be traced easily to any specific field.

\section{Sizes of Discovered Fields}

Sizes of discovered fields (except for Canada) were from the IHS Energy, Inc.

Exploration and Production database (IHS Energy, Inc., 2004); production and reserve data used were as reported at the end of 2003. Sizes of fields were defined as the sum of cumulative production plus "2P" reserves (variables OIL_RECOVERABLE_PP_MMBBL, GAS_RECOVERABLE_PP_MMSCF, and COND_RECOVERABALE_PP_MMBBL). The reported " $2 \mathrm{P}$ " (proved plus probable) reserves are generally considered estimates with a 50 percent probability of the actual values being larger. No estimates of reserve-growth potential were added, so the " $2 \mathrm{P}$ " reserve estimates may be conservative. Because of the proprietary nature of the database, the raw oil or gas field sizes cannot be released but only summary field or pool counts per bin-size class.

For Canada, the data were from the Significant Oil and Gas Pools of Canada Data Base (NRG Associates, 1995). These data are given by oil and gas pool, rather than by field, but were considered more complete than the IHS Energy, Inc. data for Canada (IHS Energy, Inc., 2004). Otherwise, calculations were performed on the pool-size data for Canadian AUs in the same 
manner as those done to the field-size data. The Canadian pool-size data are included in our database for sake of completeness. It is the option of the user as to whether that data is appropriate to use as an analog along with field-size data.

The discovered oil and gas fields (pools for Canada) were allocated to those 246 AUs of the WPA 2000 that were quantitatively assessed. Each oil or gas field was allocated to only one $\mathrm{AU}$, thus the counts per size class are all integers.

\section{World Petroleum Assessment}

The WPA 2000 (U.S. Geological Survey World Energy Assessment Team, 2000) assessed oil and gas potential in 128 provinces outside the United States. However, no attempt was made in that effort to estimate potential in all areas; it included only those areas that already had significant production or that otherwise had some particular interest. Those assessments were based on geologic studies of 159 total petroleum systems (TPS), a TPS being defined as "a mappable entity encompassing genetically related petroleum that occurs in seeps, shows, and accumulations (discovered or undiscovered) that have been generated by a pod or by closely related pods of mature source rock, together with the essential mappable geologic elements (source, reservoir, seal, and overburden rocks) that controlled fundamental processes of generation, migration, entrapment, and preservation of petroleum" (Klett and others, 2000). A hierarchical structure was developed consisting of provinces that contained TPSs that, in turn, contained AUs. Many of the TPSs were contained within one province, but some crossed province boundaries and were assigned to the most appropriate province. Within each TPS, one or more AUs were identified, for a total of 270. Of these, 246 AUs (all conventional) in 150 of the TPSs were quantitatively assessed, and form the basis of our analog database.

The WPA 2000 assessment methodology included an estimation of numbers and sizes of undiscovered accumulations for each AU (Schmoker, and Klett, 2000). The methodology is defined in terms of an accumulation, which can include either an entire field or only those reservoirs in a field that lie within a certain stratigraphic interval. For the WPA 2000, entire fields were used (pools in western Canada). The uncertainty about the number of undiscovered fields was expressed as a triangular distribution; for our database, the mean value of that distribution was used as the total number of undiscovered fields. Because that is a statistical expectation, it is not necessarily an integer.

The size distribution of undiscovered fields was approximated by a shifted truncated lognormal distribution. By integration of this distribution, the proportions of undiscovered fields in each field-size class were determined (Attanasi and Charpentier, 2007). When those proportions were multiplied by the mean number of undiscovered fields, the result was the expected number of undiscovered fields per class. Again, this is a statistical expectation, and thus not necessarily an integer. 


\section{Calculations}

The field-size distributions presented in the database are those of the entire natural population - that is, they include both discovered and undiscovered subpopulations. The basic counts of fields per size-class bin are recorded separately for discovered versus undiscovered fields in the database. Besides the basic counts of fields per size-class bin, a number of calculated parameters of the distributions are also given. Some parameters, such as the median size or the number of fields per $1,000 \mathrm{~km}^{2}$, are dependent on the minimum size assessed. For convenience, these were calculated for both a minimum of 5 million barrels of oil equivalent (MMBOE) and for a minimum of 50 MMBOE.

The actual Visual Basic for Applications macros that were used in compiling the database are preserved as part of the WorldAnalogs.xls workbook. They are included in module 4, which can be accessed within Microsoft Excel by the Visual Basic editor. Modules 1 through 3 include the code for the tools (Analog Search, Extend Selection, Analog Plot, and Analog Histogram) programmed for use with the database.

\section{Small-Field Extrapolation}

In WPA 2000, estimates were made of numbers and sizes of undiscovered fields greater than a selected minimum field size that varied from AU to AU. This minimum field size ranged from 1 to $20 \mathrm{MMBOE}$, except for pool sizes within the Western Canada Sedimentary Basin, where minimum pool size was set at $0.5 \mathrm{MMBOE}$. Because some additional analyses require estimates of smaller field sizes, an extrapolation of the size distribution into smaller field sizes is helpful.

A similar analysis of small field sizes was performed for the 1995 National Assessment of U.S. oil and gas potential (Gautier and others, 1995). An estimate of "large" undiscovered fields (defined as $1 \mathrm{MMBOE}$ or larger) was performed by an earlier version of the methodology used in the WPA 2000. An estimate of number and sizes of undiscovered fields between 31,250 BOE and 1 MMBOE was performed by a separate analysis (Root and Attanasi, 1993). This analog database used a methodology for small-field extrapolation similar to that used in 1995 (see Appendix 1).

\section{Additional Calculations}

The analog database was designed to be used as part of the USGS assessment procedures for conventional oil and gas resources (Schmoker and Klett, 2000). That methodology estimates numbers and sizes of undiscovered accumulations. The standard assessment input form is also 
documented in Schmoker and Klett (2000). Probability distributions are required for the numbers of undiscovered accumulations, the sizes of undiscovered accumulations, and for coproduct ratios (such as the gas-to-oil ratio in oil accumulations). Oil and gas accumulations are estimated separately.

The total number of fields and several parameters of the field-size distribution are dependent on the size of the smallest field considered for the assessment. Values dependent on the minimum field size are the median and maximum field sizes and the numbers of fields per $1,000 \mathrm{~km}^{2}$. For purposes of future assessments, these values were calculated for minimum field sizes of 5 and $50 \mathrm{MMBOE}$. The variables calculated for minima of 5 and $50 \mathrm{MMBOE}$ are marked in the analog dataset with names containing "> 5" and "> 50", respectively, even on those pages devoted to gas data in billions of cubic feet of gas (BCFG). Values for other minimum field sizes can be estimated based on the original binned data in the analog database.

\section{Global Distributions}

Except for the Geology worksheet, most columns of numerical variables have summary information at the bottom of the column. These data describe the "global" distribution of that variable; global, in this sense, refers to the entire set of 246 AUs in the analog database. Because the database is a biased set, preferentially containing the most successful provinces, this distribution should be characterized by larger field sizes and higher field densities than a true worldwide distribution that would also include non-productive and minimally productive areas. However, the amount of bias may be less for coproduct ratios and ancillary data, which may approximate more closely a true worldwide distribution. The global distribution is described by minimum, median, maximum, and mean values, as well as the number of AUs for which there is a value.

\section{Use of Database}

The analog database is meant to provide a source for analogs used in assessment of conventional oil and gas fields. Particularly in the case of frontier areas with few or no discovered fields, assessments must rely on comparisons to geologically similar areas that have been more maturely explored. In such frontier areas, other assessment methodologies, such as discovery process models, are unusable. Even in areas of moderately mature exploration, comparison to analogs can also be a useful check on estimates made by other methods. Although constructed with the USGS methodology in mind, the database can be used with other methodologies.

The foregoing is not to imply that resource assessment is the only use for our analog database. More than 95 percent of the world's discovered oil and gas resources as of the end of 1995 (excluding the United States) are in the 246 AUs included in the database, thus it offers additional opportunities for analysis of patterns of oil and gas occurrence. 
The examples presented below are based on constructing sets of analogs, but analyses may be based on any number from one to all 246 AUs. Although some may prefer to search for a single "best" analog, the construction of a set of analogs better characterizes the range of uncertainty.

For a particular assessment, more than one set of analogs may be necessary. Numbers and sizes of fields are commonly constrained by the available trapping configurations, which in turn are related to the tectonic and sedimentologic characteristics of the area. Coproduct ratios, such as the gas-to-oil ratio in oil fields, relate more closely to source rock characteristics and thermal history. A different set of analogs may thus be appropriate for assessing the coproduct ratios.

\section{Classification Variables}

The first worksheet (Geology) of the analog database workbook includes 34 variables (referred to as classification variables) that allow the user to classify the AUs and thus select appropriate analogs (table 2). (Note: For those using the tab-delimited files, this is file "geology.tab.") The first six variables identify the assessment unit and place it into the hierarchical structure of province and total petroleum system. The other variables relate either to (1) province-scale geology, such as the tectonic regime or basin type; or (2) assessment-unitscale geology, such as the source, reservoir, and trap characteristics. This geologic information was compiled as part of the WPA 2000 (U.S. Geological Survey World Energy Assessment Team, 2000), mostly from the text summaries describing each assessment unit. 
Table 2. Classification variables in the world analog database and the allowed values for those variables with a limited range of values [AU, assessment unit; TPS, total petroleum system; BBO, billion barrels of oil; TCFG, trillion cubic feet of gas; BBNGL, billion barrels of natural gas liquids; BBOE, billion barrels of oil equivalent]

\begin{tabular}{|c|c|c|}
\hline Variable & Description & Values Allowed \\
\hline AU_Code & USGS code for this assessment unit & \\
\hline AU_Name & official USGS name for this assessment unit & \\
\hline TPS̄_Code & USGS code for this total petroleum system & \\
\hline TPS_Name & $\begin{array}{l}\text { official USGS name for this total petroleum } \\
\text { system }\end{array}$ & \\
\hline Province Code & USGS code for this province & \\
\hline Province Name & official USGS name for this province & \\
\hline \multirow[t]{4}{*}{ Structural Setting } & & Compressional \\
\hline & & Extensional \\
\hline & & Passive \\
\hline & & Unknown \\
\hline \multirow[t]{4}{*}{ Crustal System } & & Continental \\
\hline & & Oceanic \\
\hline & & Transitional \\
\hline & & Uncertain \\
\hline \multirow[t]{9}{*}{ Architecture } & & Backarc \\
\hline & & Craton interior \\
\hline & & Deltas \\
\hline & & Foreland \\
\hline & & Platform \\
\hline & & Rift, sag \\
\hline & & Rifted passive margin \\
\hline & & Small ocean basin \\
\hline & & Strike-slip systems \\
\hline \multirow[t]{6}{*}{ Trap System (Major) } & & Basement-involved block structures \\
\hline & & Compressional anticlines, folds, thrusts \\
\hline & & Diapir-related structures \\
\hline & & $\begin{array}{l}\text { Extensional grabens and other structures } \\
\text { related to normal faulting }\end{array}$ \\
\hline & & Gravity-induced growth faults \\
\hline & & Local uplifts of uncertain origin \\
\hline
\end{tabular}


Paleogeomorphic

Salt-induced structures

Stratigraphic undeformed

Transtensional and transpressional

Depositional System

Carbonate shelf

Carbonate shelf margin, reefs

Continental clastics

Deepwater carbonates

Paralic clastics

Slope, clinoforms, turbidites

Source Rock Depositional Environment

Coaly

Deep marine

Lacustrine

Shallow marine

Kerogen Type

No source rocks

Type II

Type III

Types I and II

Types II and III

Types I, II, and III

Source Type

Anoxic/disoxic

Carbonaceous mudstones, coal

Disoxic/oxic

Lacustrine anoxic/dioxic

Marine anoxic

Marine disoxic

Terrestrial

Source Rock Qualifier

Assumed

Known

Probable

Status

Hypothetical

Established

Frontier

Specific Reservoir Rock Age

various

General Reservoir Rock Age

various

Reservoir Rock Lithology

Carbonates 
Siliclastics

Siliciclastics and Carbonates

Siliciclastics, Carbonates, and Other

Reservoir Rock Depositional

Environment

Deep marine

Nonmarine

Nonmarine to Marine

Shallow Marine

Shallow to Deep Marine

\section{Seal Rock Lithology}

\section{Evaporites}

Evaporites and Shale

Shale

Trap Type

general trap type

Stratigraphic

Structural

Structural and Stratigraphic

\begin{tabular}{|c|c|c|}
\hline Known Oil (BBO) & cumulative production plus reserves of oil & \\
\hline Undiscovered Oil (Mean, BBO) & $\begin{array}{l}\text { mean USGS estimate of oil in undiscovered } \\
\text { fields }\end{array}$ & \\
\hline Known Gas (TCFG) & $\begin{array}{l}\text { cumulative production plus reserves of natural } \\
\text { gas }\end{array}$ & \\
\hline Undiscovered Gas (Mean, TCFG) & $\begin{array}{l}\text { mean USGS estimate of natural gas in } \\
\text { undiscovered fields }\end{array}$ & \\
\hline Known NGL (BBNGL) & cumulative production plus reserves of NGL & \\
\hline Undiscovered NGL (Mean, BBNGL) & $\begin{array}{l}\text { mean USGS estimate of NGL in undiscovered } \\
\text { fields }\end{array}$ & \\
\hline Known Total Petroleum (BBOE) & $\begin{array}{l}\text { cumulative production plus reserves of } \\
\text { petroleum in } \mathrm{BOE}\end{array}$ & \\
\hline $\begin{array}{l}\text { Undiscovered Total Petroleum (Mean, } \\
\text { BBOE) }\end{array}$ & $\begin{array}{l}\text { mean USGS estimate of petroleum in } \\
\text { undiscovered fields (in BOE) }\end{array}$ & \\
\hline Specific Source Rock Age & & various \\
\hline General Source Rock Age & & various \\
\hline Age of Maturation & & various \\
\hline Migration Distance & & $\begin{array}{l}\text { Short } \\
\text { Short to long }\end{array}$ \\
\hline
\end{tabular}




\section{Methods of Searching}

For those using the Microsoft Excel version of the database, tools have been developed for easier use. These are located under the Analog menu in the menu bar. Two of these, Analog Search and Extend Selection, are aids to searching and building analog sets for further analysis.

Analog Search, found under the Analog menu in the menu bar, is a tool for simple searches on several of the most important geologic variables. An initial form asks whether to search within the current selection. This allows multi-level (Boolean AND) searches. Next, the tool provides a pop-up menu of the most important classification variables (fig. 1). Following selection of one of the variables, another pop-up menu provides a list of the possible values for that variable (fig. 2). The results of the search are highlighted on all the worksheets of the database. 


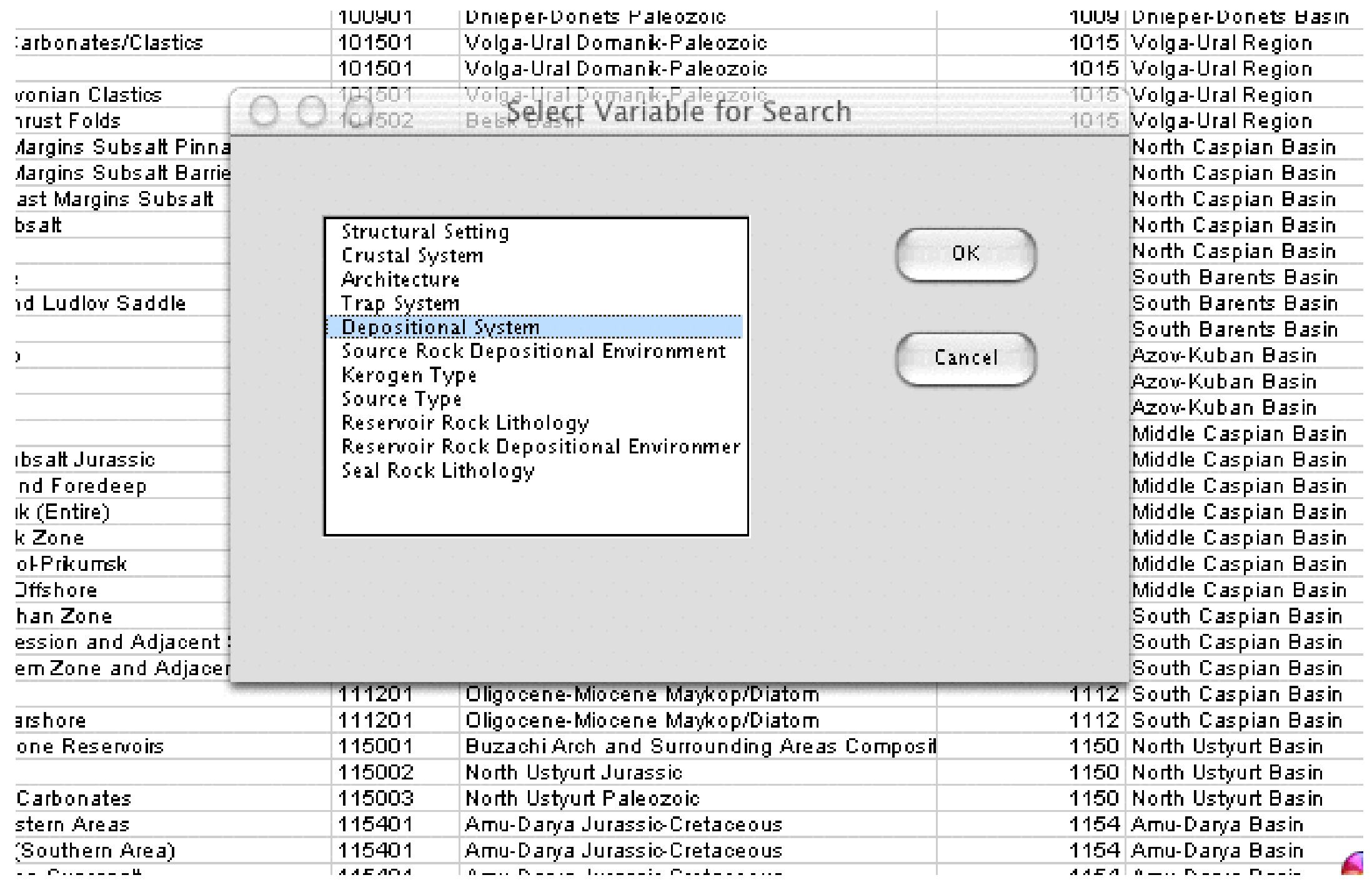

Figure 1. Select variables form for the Analog Search tool. 


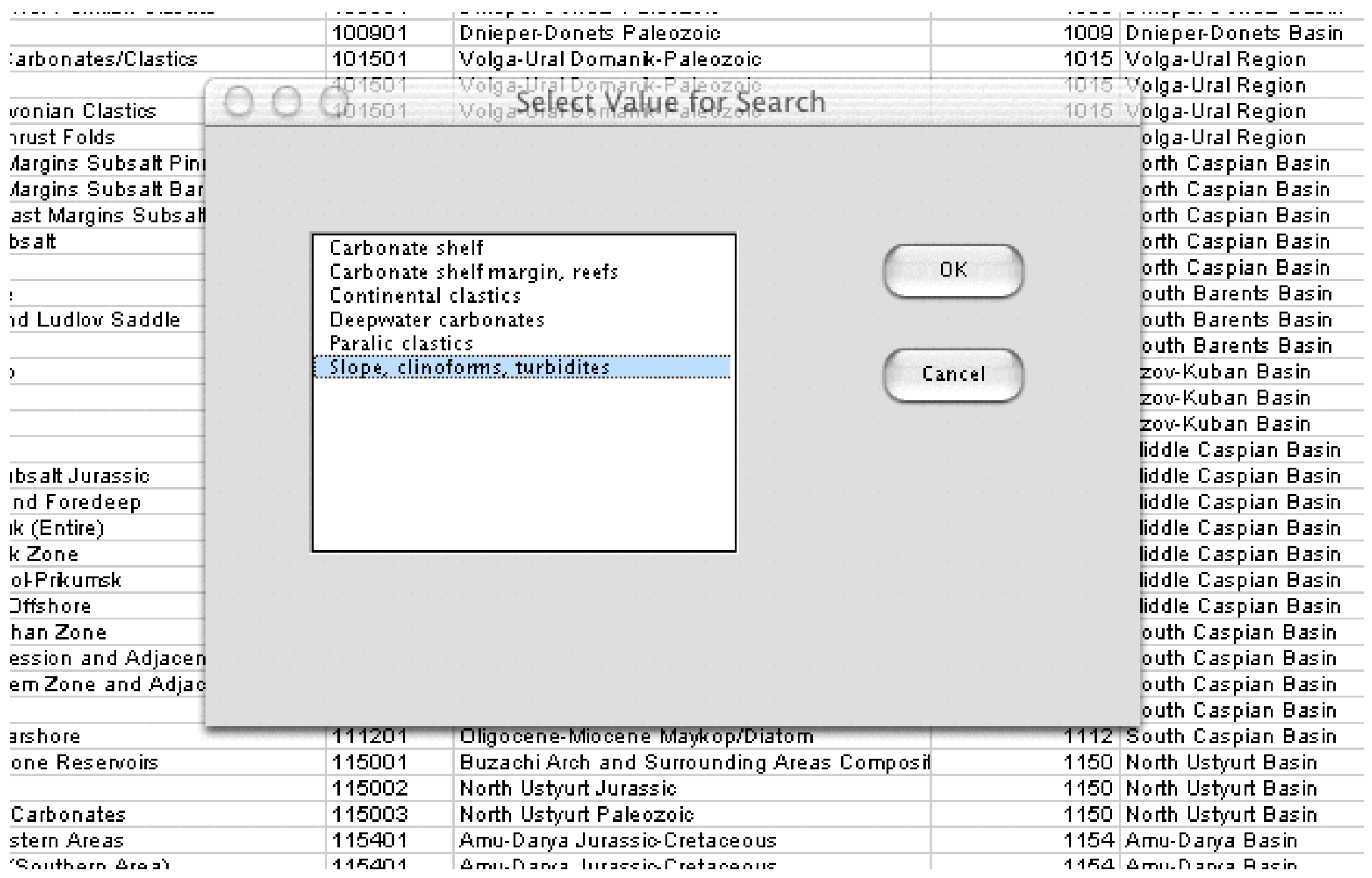

Figure 2. Select values form for the Analog Search tool. 
Microsoft Excel users can use the other search capabilities built into the program, such as the Find or Filter commands or manually selecting with the mouse. The Extend Selection command can be used in conjunction with these search methods. Extend Selection finds all selected cells in the Geology worksheet and extends the selection such that the entire row is selected for each row with a selected cell. The selection is further extended to all the other worksheets in the database. As an example, one could manually select all the cells in column Specific Source Rock Age (column AE) on the Geology worksheet that had value "Devonian". Running Extend Selection would thus select the entire row for each of those chosen AUs on all the worksheets. Microsoft Excel users who create selections on the Geology worksheet other than by Analog Search and wish to use the additional graphing tools Analog Plot and Analog Histogram should run Extend Selection before using the graphing tools.

For users of other spreadsheet programs, searching for a set of analogs can be accomplished by use of tools specific to the user's spreadsheet program. The tools Analog Search and Extend Selection are not available outside the Microsoft Excel version of the analog database.

\section{Utility Variables}

Utility variables are so named because they can be used for analysis once an analog set has been selected. Most of the major utility variables are on the Oil, Gas, and BOE worksheets. Additional utility variables are on the Oil Bins, Gas Bins, BOE Bins, and Ancillary worksheets.

\section{Variables Related to Number of Fields}

The Oil Bins, Gas Bins, and BOE Bins worksheets contain the basic numbers of discovered and undiscovered fields in each size class. Most users will not want to use such basic data, but instead will use some of the summary data variables. These worksheets include totals of "Number of Discovered," "Number of Undiscovered," as well as "Number > 5," and "Number $>50$." The latter two variables give the number of fields greater than the minima of 5 and 50 MMBOE respectively.

Because neither 5 nor $50 \mathrm{MMBOE}$ are exact bin limits, the numbers of fields greater than these minimum sizes had to be estimated. For number of fields of at least $5 \mathrm{MMBOE}$, the counts from bin sizes $8 \mathrm{MMBOE}$ and larger are added to two-thirds the number in the 4 to $8 \mathrm{MMBOE}$ size class. For number of fields of at least $50 \mathrm{MMBOE}$, the counts from bin sizes $64 \mathrm{MMBOE}$ and larger are added to one-third the number in the 32 to 64 MMBOE size class.

Perhaps more useful for calculating numbers of undiscovered fields in an area to be assessed are several variables listed on the Oil, Gas, and BOE worksheets. Here the variables "Number $/ 1000 \mathrm{~km}^{2}$ for $>5$," and "Number $/ 1000 \mathrm{~km}^{2}$ for $>50$ " give field densities per 1,000 $\mathrm{km}^{2}$ rather than raw numbers of fields. 


\section{Variables Related to Field Size Distributions}

The raw field-size bin counts for each analog AU are given in the Oil Bins, Gas Bins, and BOE Bins worksheets. More useful to the assessor are several variables in the Oil, Gas, and BOE worksheets: "Median of $>5$," "Median of $>50$," "Maximum of $>5$," and "Maximum of $>50$ ", which give the medians and maxima of the size distributions of those fields greater than the minima of 5 and $50 \mathrm{MMBOE}$, respectively.

Median sizes are approximated from the bin count data. The bin counts were used to identify the bin that included the median field size, which was calculated within that bin by interpolation.

The variables "Maximum of $>5$ " and "Maximum of $>50$ " are defined as the maximum size of discovered fields (column BB in the bins worksheets) or the expected (mean) size of the largest undiscovered field (column $\mathrm{BC}$ in the bins worksheets), whichever is larger. In order to preserve the proprietary field-size data, the maximum size of discovered fields is rounded to 1.38 times the lower limit of the bin in which it resides. The variables "Maximum of $>5$ " and "Maximum of $>50$ " are different only in the case where the maximum size is between 5 and 50 MMBOE. In that case there would be a value for "Maximum of $>5$ " but not for "Maximum of $>$ 50."

\section{Variables Related to Maturity of Exploration}

Four utility variables are provided as indices of exploration maturity. These are "Discovered \% by Number for $>5$," "Discovered \% by Number for $>50$," "Discovered \% by Volume for $>5$," and "Discovered $\%$ by Volume for $>50$," all of which are listed on the Oil, Gas, and BOE worksheets. These maturity measures are used by the Analog Plot tool described below.

\section{Variables Related to Coproduct Ratios}

The methodology used in the WPA 2000 treated fields as being either oil or gas (Schmoker and Klett, 2000). Oil fields are differentiated from gas fields in that they have a gasto-oil ratio (based on cumulative production plus reserves) of less than 20 thousand cubic feet per barrel. Field sizes are expressed as volumes of oil in oil fields and volumes of gas in gas fields, a procedure that was followed in the analog database. Other petroleum products are handled by the use of coproduct ratios. In oil fields, associated and dissolved gas volumes are calculated using a gas-to-oil ratio and natural gas liquids (NGL) volumes are calculated using a NGL-to-gas ratio. In gas fields, total liquids are calculated using a liquids-to-gas ratio. These three coproduct ratios are provided in the analog database - the two coproduct ratios for oil fields are on the Oil worksheet, the coproduct ratio for gas fields is on the Gas worksheet, and all three coproduct ratios are on the BOE worksheet.

Data provided for coproduct ratios in the analog database is based on production and reserves data from discovered fields drawn from the IHS Energy, Inc.(2004), and NRG Associates (1995) databases. Coproduct ratios for individual fields were calculated from the 
cumulative production plus reserves of each product. Each field was allocated to a particular AU. The analog database contains five variables describing the distribution of each coproduct ratio - minimum, median, maximum, and mean, as well as the number of fields that had a calculated coproduct ratio of that type. The number of fields gives an indication of the confidence in the other measures. A small number of fields indicates poorer sampling, and the distribution is thus known with less confidence.

\section{Variables Related to Ancillary Data}

Ancillary data are not used to calculate volumes of undiscovered resources, but rather give information affecting the technical and economic recoverability of the resource. Some ancillary variables describe the quality of the oil and gas fluids: oil viscosity (in centipoises and in centistokes), API gravity of the oil, sulfur content of the oil in percent, and non-hydrocarbon fractions of the gas (percentages of hydrogen sulfide, carbon dioxide, and nitrogen). The ancillary data also include drilling depths and, for the offshore, water depths (in feet). As with the coproduct ratios, the data in the analog database comes from discovered fields only. The ancillary data are presented on worksheet Ancillary.

The ancillary data are presented in a manner similar to that of the coproduct data. There are five variables describing the distribution of each ancillary variable - minimum, median, maximum, and mean, as well as the number of fields that had a ancillary value of that type. The number of fields gives an indication of the confidence in the other measures. A small number of fields indicates poorer sampling, and the distribution is thus known with less confidence.

\section{Data Analysis Tools}

Several tools added to the Microsoft Excel version of the analog database can be accessed through the menu bar under Analog; to use, the analog set should first be selected on the Geology worksheet. If the selection is made manually, the program Extend Selection (under the Analog menu in the menu bar) should be run before using the data analysis tools.

\section{Distributions for Small Analog Sets}

For small analog sets (those with fewer than about 20 AUs), an additional graphing tool has been added to the Microsoft Excel version of the database. This tool, Analog Plot, can be found under the Analog menu in the menu bar. The resulting graph shows the distribution of a selected utility variable for the analog set selected in the Geology worksheet.

Each analog AU is represented on the graph by a vertical bar placed at the value of the utility variable (fig. 3). The length of the shaded portion of the bar is a maturity measure showing the percent of resource already discovered. The user may choose either percent by volume (suggested) or percent by number of fields to show maturity. Values of the utility variable are more credible for those AUs with higher maturity. Each bar is labeled by the AU name. 
Rift-Sag

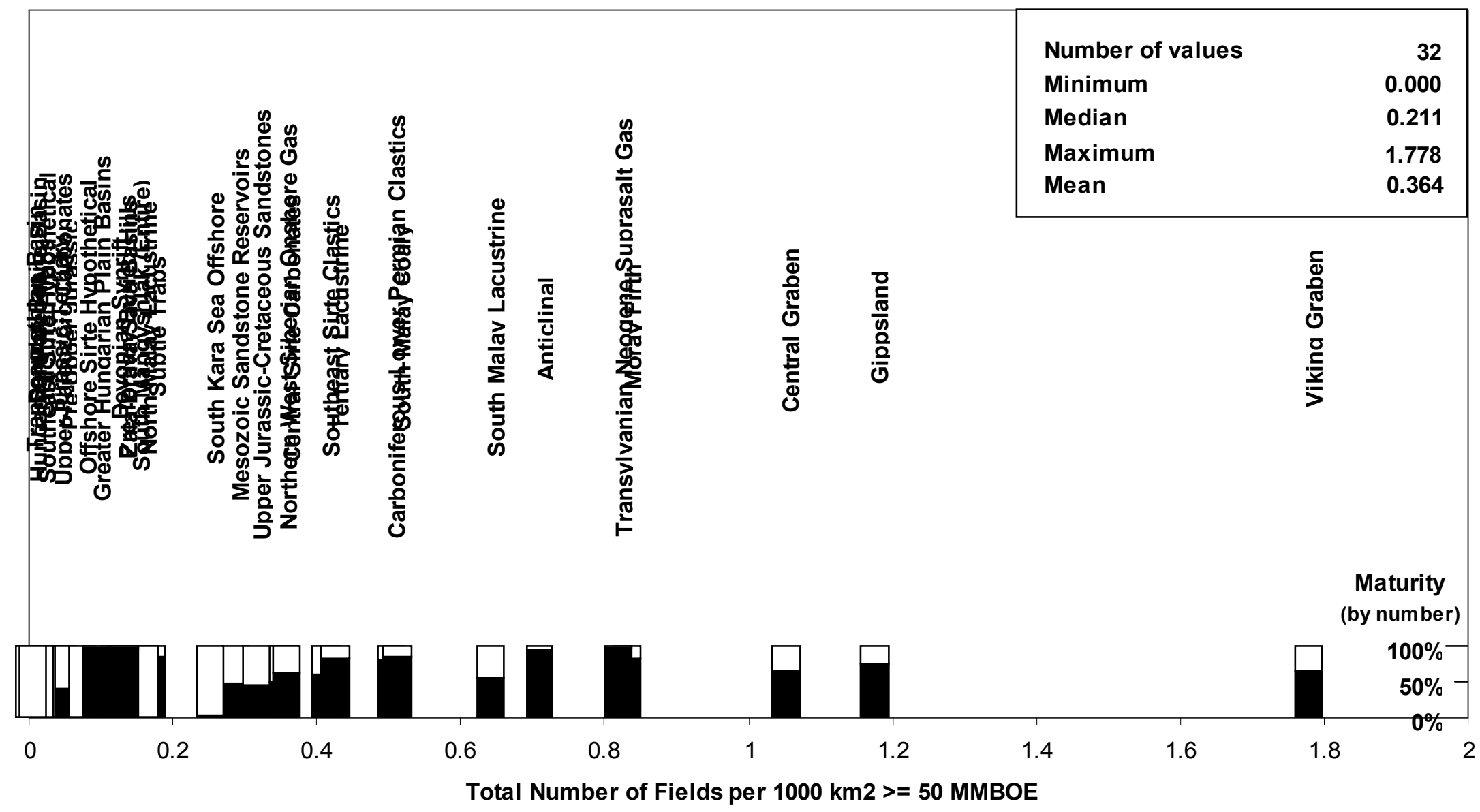

Figure 3. Example of chart generated by the Analog Plot tool. MMBOE, million barrels of oil equivalent. 
A large number of analogs with similar values of the utility variable in question can lead to an unreadable chart. In such a case, one could remove AUs with extreme values from the analog set, thus changing the $\mathrm{X}$-axis scale. Alternatively, one could use the Analog Histogram tool.

In constructing the plot (as in fig. 3), data are copied to worksheet Chart Data. Column A contains the values of the utility variable in ascending sorted order. Column B contains the maturity measures for the data in column A. The distribution of the utility variable data in column A is summarized in column $\mathrm{K}$, where the number of values, minimum, median, maximum, and mean are given. These data are replaced when a new chart is constructed either by Analog Plot or by Analog Histogram.

\section{Distributions for Large Analog Sets}

For large analog sets (those with more than about 20 AUs), another graphing tool has been added to the Microsoft Excel version of the database. This tool, Analog Histogram, can also be found under the Analog menu in the menu bar. The resulting graph shows the distribution of a selected utility variable for the analog set selected in the Geology worksheet. With this tool a distribution histogram is constructed but no maturity measure or identification of AU names is given (fig. 4). 


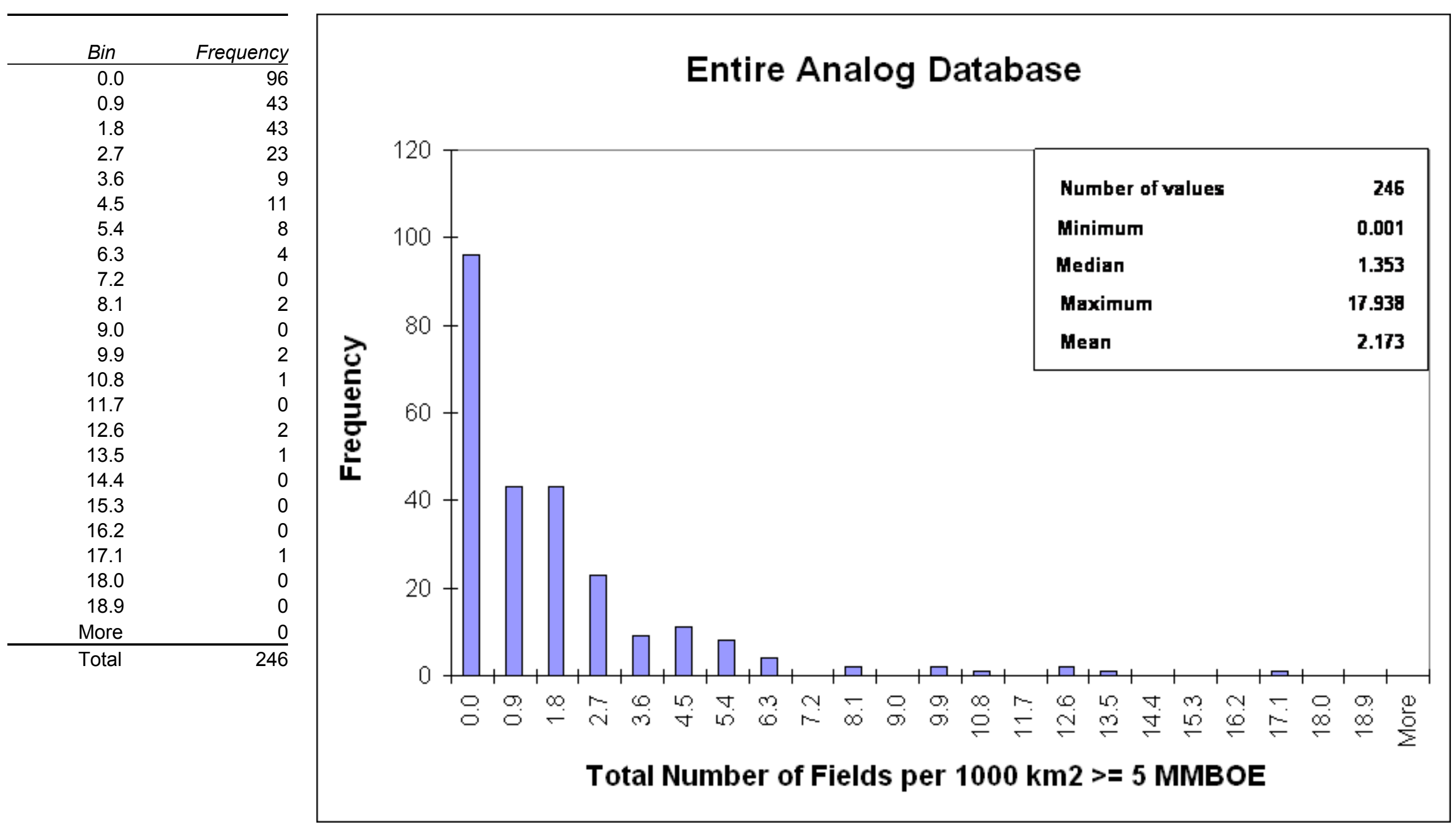

Figure 4. Example of chart generated by the Analog Histogram tool. MMBOE, million barrels of oil equivalent. 
In constructing the histogram, data are copied to worksheet Chart Data. Column A contains the values of the utility variable in ascending sorted order. Column $\mathrm{H}$ contains the histogram class boundaries. The distribution of the utility variable data in column A is

summarized in column $\mathrm{K}$, where the number of values, minimum, median, maximum, and mean are given. These data are replaced when a new chart is constructed either by Analog Plot or by Analog Histogram.

\section{Example of Use with USGS Assessment Methodology}

The following example is based on the standard 2000 USGS methodology for assessing conventional oil and gas resources (Schmoker and Klett, 2000). The assessment input form (fig. 5) requires distributions for numbers and sizes of oil and gas accumulations and the associated coproduct ratios 
Figure 5. Seventh approximation input data form, version 6 .

SEVENTH APPROXIMATION

DATA FORM FOR CONVENTIONAL ASSESSMENT UNITS (Version 6, 9 April 2003)

IDENTIFICATION INFORMATION

Assessment Geologist:

Region:

Province:

Total Petroleum System:

Assessment Unit:

Based on Data as of:

Notes from Assessor:

Date:

Number:

Number:

Number:

Number:

\section{CHARACTERISTICS OF ASSESSMENT UNIT}

Oil ( $<20,000 \mathrm{cfg} / \mathrm{bo}$ overall) or Gas $(\geq 20,000 \mathrm{cfg} / \mathrm{bo}$ overall):

What is the minimum accumulation size?

(the smallest accumulation that has potential to be added to reserves)

No. of discovered accumulations exceeding minimum size:

Established ( $>13$ accums.)

Frontier (1-13 accums.)

Oil: Gas:

Median size (grown) of discovered oil accumulations (mmbo):

1 st 3 rd

2nd 3rd 3ra 3rd

Median size (grown) of discovered gas accumulations (bcfg):

1st 3rd

2nd 3rd 3rd 3rd

Assessment-Unit Probabilities:

Attribute

Probability of occurrence (0-1.0)

1. CHARGE: Adequate petroleum charge for an undiscovered accum. $\geq$ minimum size:

2. ROCKS: Adequate reservoirs, traps, and seals for an undiscovered accum. $\geq$ minimum size:

3. TIMING OF GEOLOGIC EVENTS: Favorable timing for an undiscovered accum. $\geq$ minimum size

Assessment-Unit GEOLOGIC Probability (Product of 1,2, and 3)

4. ACCESSIBILITY: Adequate location to allow exploration for an undiscovered accumulation $\geq$ minimum size:

UNDISCOVERED ACCUMULATIONS

No. of Undiscovered Accumulations: How many undiscovered accums. exist that are $\geq$ min. size?: (uncertainty of fixed but unknown values)

Oil Accumulations:

Gas Accumulations

minimum $(>0)$

mode

minimum $(>0) \longrightarrow \bmod$ maximum

Sizes of Undiscovered Accumulations: What are the sizes (grown) of the above accums?

(variations in the sizes of undiscovered accumulations)

Oil in Oil Accumulations (mmbo)

Gas in Gas Accumulations (bcfg):

minimum

minimum median

median maximum maximum 
Assessment Unit (name, no.)

AVERAGE RATIOS FOR UNDISCOVERED ACCUMS., TO ASSESS COPRODUCTS

(uncertainty of fixed but unknown values)

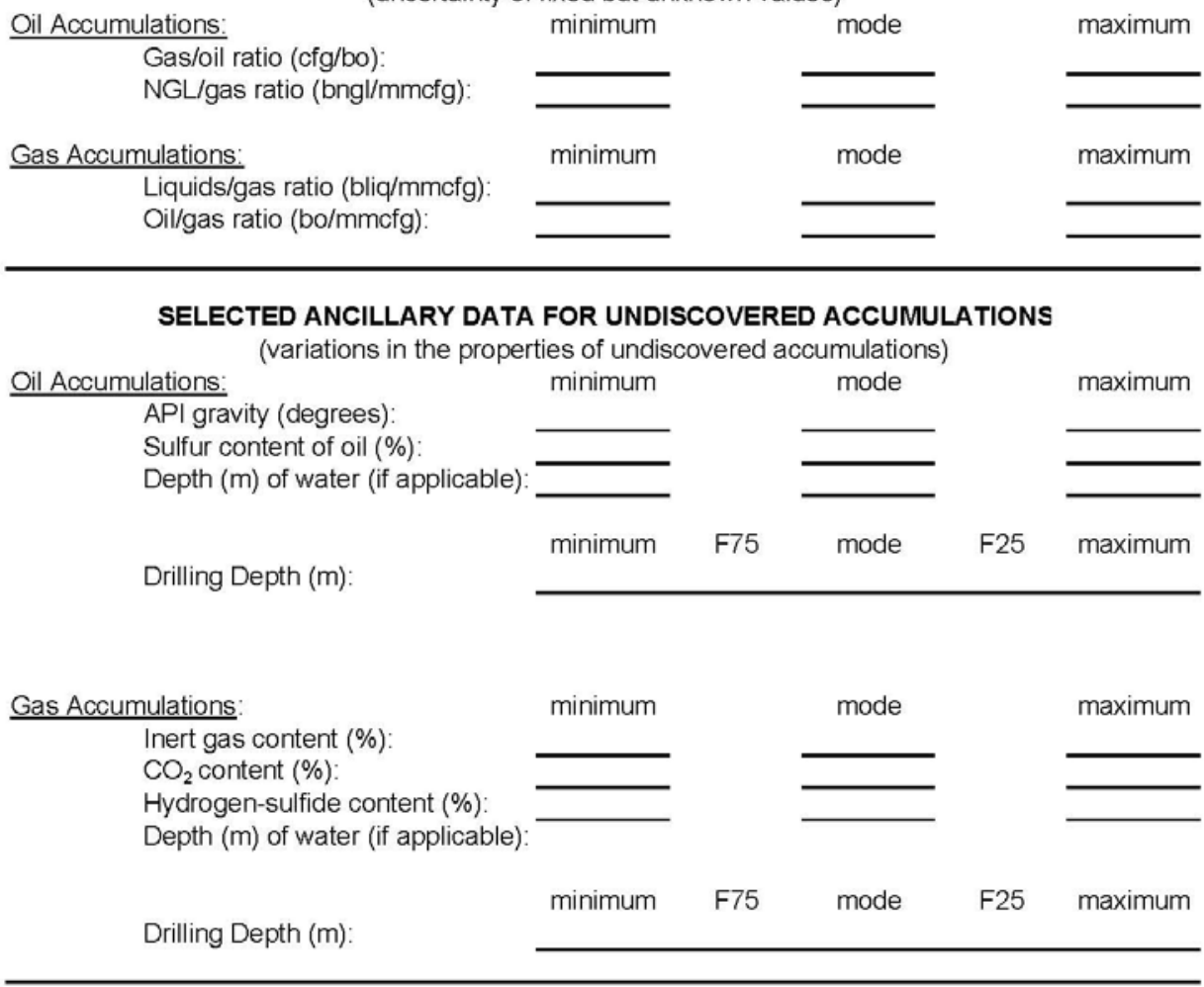




\section{Selection of Analogs}

The example AU is in a deep-water environment with possible turbidite reservoirs; its area is $100,000 \mathrm{~km}^{2}$. No fields have yet been discovered in this area. A minimum assessed size of 5 MMBOE will be used.

In order to choose a suitable set of analogs, a search was conducted using the Analog Search tool, within which the Depositional System variable (fig. 1) was searched for values that included "Slope, clinoforms, turbidites" (fig. 2). This yielded a set of 44 potential analogs (table 3). Further examination could refine this analog set to a smaller number of analogs that are geologically more similar to the area being assessed, but with some possible loss of insight into the uncertainty.

Table 3. Analog set for the numbers and sizes of fields used in text example (based on a search for the value "Slope, clinoforms, and turbidites" within the Depositional System variable)

\begin{tabular}{ll}
\hline & Assessment Unit Number and Name \\
\hline 11120104 & Central Offshore \\
11120105 & Iran Onshore/Nearshore \\
11740101 & Upper Jurassic-Cretaceous Sandstones \\
20160201 & Natih-Fiqa Structural/Stratigraphic \\
37010102 & Brunei-Sabah Turbidites \\
38170102 & Kutei Basin Turbidites \\
39100201 & Petrel \\
39100301 & Malita \\
39130101 & Late Jurassic/Early Cretaceous-Mesozoic \\
39480101 & Dingo-Mungaroo/Barrow \\
39480201 & Locker-Mungaroo/Barrow \\
40250103 & Central Graben \\
40470101 & Foreland Basin \\
40470201 & Deformed Belt \\
40480101 & Greater Hungarian Plain Basins \\
40480201 & Zala-Drava-Sava Basins \\
40480601 & Hungarian Paleogene Basin \\
40600101 & Neogene Flysch Gas \\
60210101 & Late Cretaceous-Tertiary Turbidites \\
60220101 & Amazon Delta and Submarine Fan \\
60290102 & Late Cretaceous-Tertiary Deep-Water Sandstones \\
60340102 & Late Cretaceous-Tertiary Slide Blocks and Turbidites \\
60340103 & Abrolhos Sub-Volcanic Structures \\
60350101 & Late Cretaceous-Tertiary Turbidites \\
60350103 & Salt Dome Province Tertiary Sandstones \\
60360102 & Salt-Structured Deep-Water Sandstones \\
60370101 & Pelotas Platform and Basin \\
60450101 & Sub-Andean Fold and Thrust Belt \\
\hline
\end{tabular}




$\begin{array}{ll}60450102 & \text { Foreland Basins } \\ 60550103 & \text { Dorsal de Neuquen Structure } \\ 60980202 & \text { Orinoco Delta and Offshore } \\ 61030101 & \text { Carupano Basin Gas } \\ 61070101 & \text { Inner Forearc Deformation Belt } \\ 71920102 & \text { Akata Reservoirs } \\ 72030201 & \text { Gabon Suprasalt } \\ 72030302 & \text { Central Congo Turbidites } \\ 72030401 & \text { Cuanza-Namibe } \\ 73030101 & \text { Offshore } \\ 80420102 & \text { Indus Fan } \\ 80430102 & \text { Eocene-Miocene Cambay Deltaic } \\ 80470201 & \text { Western Shelf and Slope } \\ 80470301 & \text { Central Basin } \\ 80470302 & \text { Eastern Fold Belt } \\ 80480102 & \text { Irrawaddy-Andaman }\end{array}$

\section{Numbers of Fields}

To capture the uncertainty in number of undiscovered fields, the density of fields per $1,000 \mathrm{~km}^{2}$ was examined in the analog set. A minimum size of $5 \mathrm{MMBOE}$ was used and the density of total fields was examined. Because of the relatively large number of analogs (more than 20), the Analog Histogram tool was used instead of the Analog Plot tool. Based on this set of 44 analogs, the field density ranges to about 10 fields per $1,000 \mathrm{~km}^{2}$, but most values are from 0 to 2 fields per $1,000 \mathrm{~km}^{2}$ (fig. 6). 


\begin{tabular}{rr}
\hline Bin & Frequency \\
\hline 0.0 & 8 \\
0.5 & 9 \\
1.0 & 8 \\
1.5 & 4 \\
2.0 & 2 \\
2.5 & 3 \\
3.0 & 0 \\
3.5 & 2 \\
4.0 & 1 \\
4.5 & 2 \\
5.0 & 2 \\
5.5 & 1 \\
6.0 & 1 \\
6.5 & 0 \\
7.0 & 0 \\
7.5 & 0 \\
8.0 & 0 \\
8.5 & 0 \\
9.0 & 0 \\
9.5 & 0 \\
10.0 & 1 \\
10.5 & 0 \\
More & 0 \\
\hline Total & 44 \\
&
\end{tabular}

\section{Slope, Clinoforms, Turbidites}

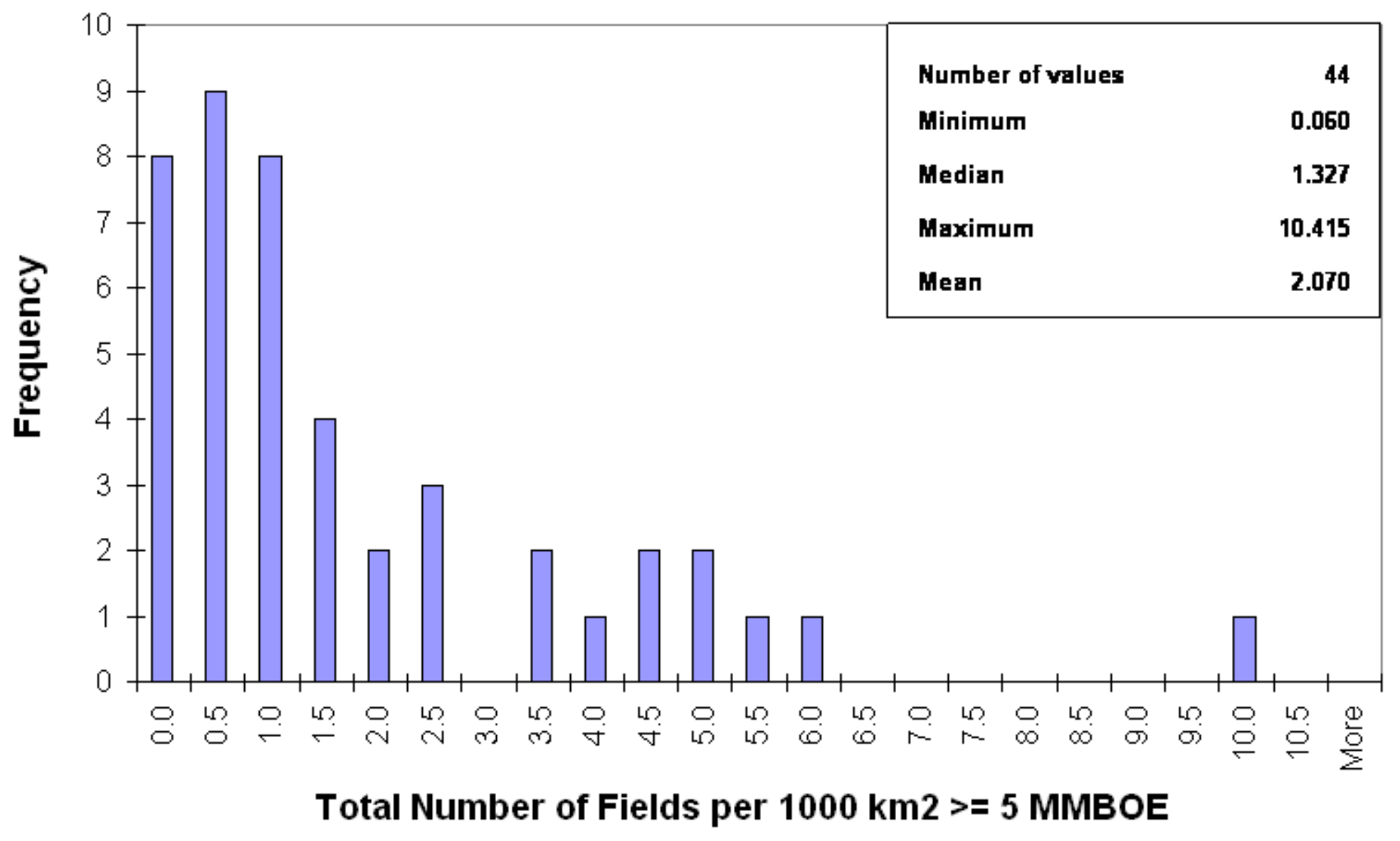

Figure 6. Plot of field density per $1,000 \mathrm{~km}^{2}$ for example given in text. MMBOE, million barrels of oil equivalent. 
Values appropriate to the input form (fig. 5) should reflect these densities. A possible modal number of oil plus gas fields could be approximately 1 field per $1,000 \mathrm{~km}^{2}$ times the area of the AU, or 100 total fields. Dividing this number of fields between oil and gas fields is dependent on an understanding of source rocks and thermal history. Any previously discovered fields would need to be subtracted from these numbers. Similarly, the maximum number of oil plus gas fields could be as high as 10 fields per $1,000 \mathrm{~km}^{2}$ times the area of the AU, or 1,000 total fields (to be divided between oil and gas fields).

\section{Sizes of Fields}

In a similar manner, uncertainty in sizes of undiscovered fields requires examination of the median and maximum field sizes in the analog set. A minimum size of $5 \mathrm{MMBOE}$ was again used and the sizes of total fields were examined. Because of the relatively large number of analogs (more than 20), the Analog Histogram tool was used instead of the Analog Plot tool. The median field sizes range from 8 to more than $25 \mathrm{MMBOE}$ (fig. 7), with most values about 14 MMBOE. One of the values for maximum field size exceeds 22,000 MMBOE (fig. 8), but all the others are less than $3 \mathrm{MMBOE}$. 


\begin{tabular}{|c|c|}
\hline Bin & Frequency \\
\hline 0 & 0 \\
\hline 2 & 0 \\
\hline 4 & 0 \\
\hline 6 & 0 \\
\hline 8 & 1 \\
\hline 10 & 2 \\
\hline 12 & 19 \\
\hline 14 & 12 \\
\hline 16 & 3 \\
\hline 18 & 3 \\
\hline 20 & 3 \\
\hline 22 & 0 \\
\hline 24 & 0 \\
\hline 26 & 1 \\
\hline 28 & 0 \\
\hline 30 & 0 \\
\hline 32 & 0 \\
\hline 34 & 0 \\
\hline 36 & 0 \\
\hline 38 & 0 \\
\hline 40 & 0 \\
\hline 42 & 0 \\
\hline More & 0 \\
\hline Total & 44 \\
\hline
\end{tabular}

Slope, Clinoforms, Turbidites

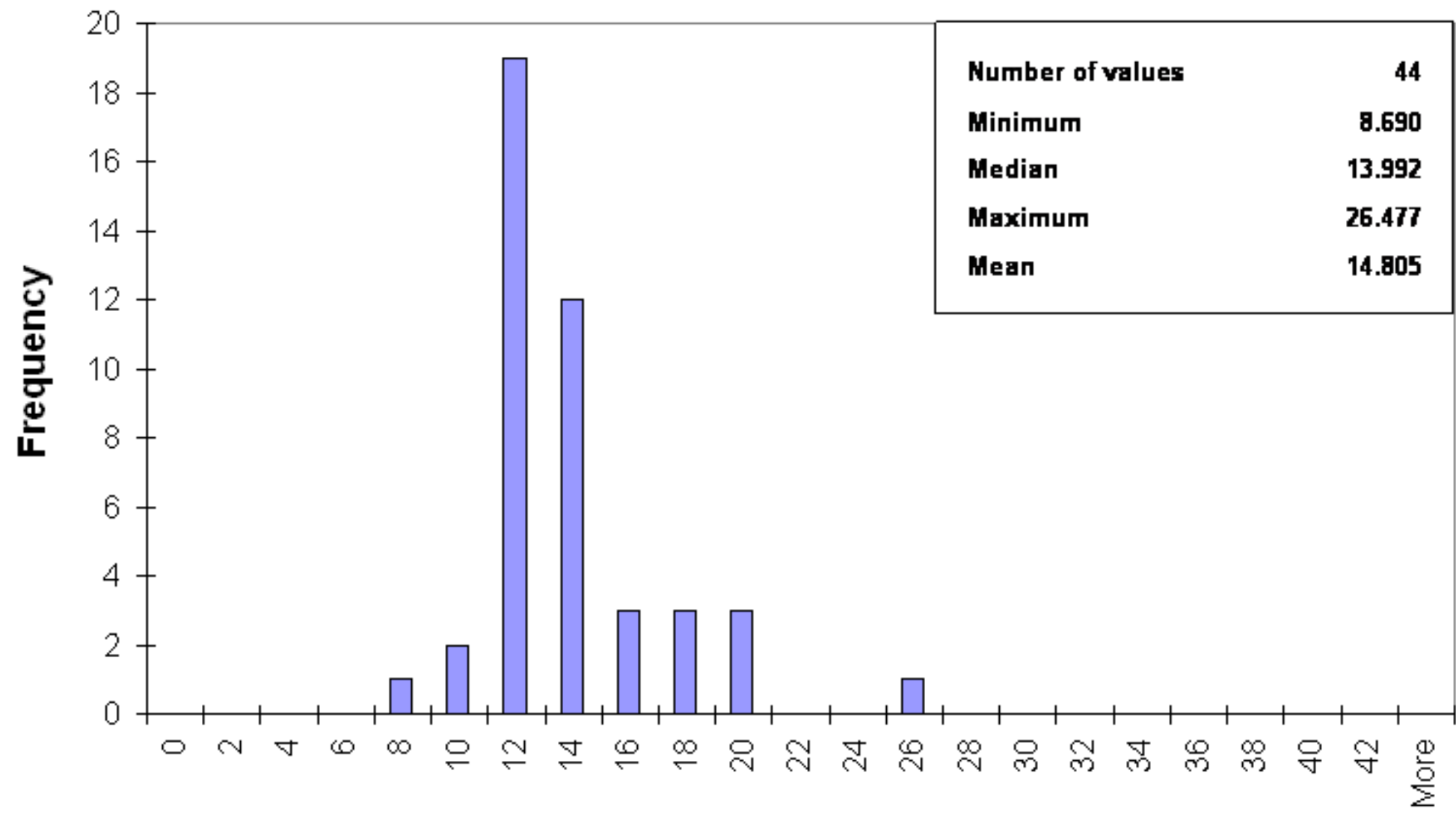

Median Size of All Fields $>=5$ MMBOE

Figure 7. Plot of median field size for example given in text. MMBOE, million barrels of oil equivalent. 


\begin{tabular}{rr}
\hline Bin & Frequency \\
\hline 0 & 30 \\
1190 & 8 \\
2380 & 5 \\
3570 & 0 \\
4760 & 0 \\
5950 & 0 \\
7140 & 0 \\
8330 & 0 \\
9520 & 0 \\
10710 & 0 \\
11900 & 0 \\
13090 & 0 \\
14280 & 0 \\
15470 & 0 \\
16660 & 0 \\
17850 & 0 \\
19040 & 0 \\
20230 & 0 \\
21420 & 1 \\
22610 & 0 \\
23800 & 0 \\
24990 & 0 \\
More & 0 \\
\hline Total & 0 \\
& 0 \\
\hline
\end{tabular}

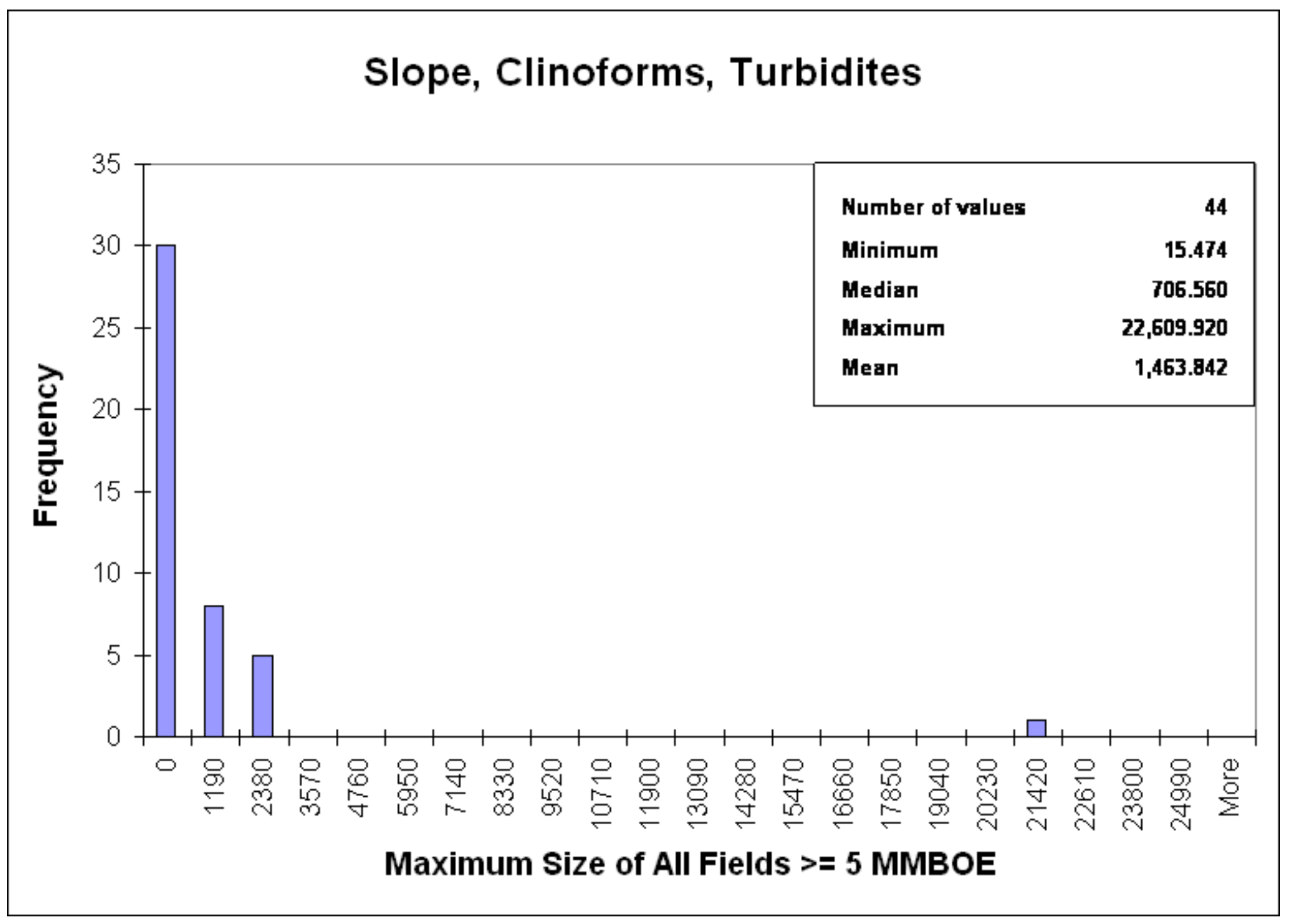

Figure 8. Plot of maximum field size for example given in text. MMBOE, million barrels of oil equivalent. 
The values appropriate to the input form (fig. 5) should reflect these densities. The minimum size was defined in this example as 5 MMBOE. The median size could be about 14 MMBOE. Because the data for maximum field size include an outlier value much larger than any of the others, the analog AU containing that value should be closely examined for geologic similarity to the others in the analog set. If this AU cannot be reasonably eliminated from the analog set, the high uncertainty suggests a maximum size in the 25,000 MMBOE range. Also, any previously discovered fields could reduce the maximum undiscovered field size.

\section{Coproduct Ratios}

The coproduct ratios relate to a different set of geologic characteristics than the numbers and sizes of fields, so a different set of analogs is required. In this example case, we chose analogs that have lacustrine source rock depositional environments and types I and II kerogen (table 4). Distributions of the three coproduct ratios are given in figures 9,10 , and 11 . The smaller (22) size of the analog set allows use of the Analog Plot tool. Although this is a small analog set, a distribution of values for each of the coproduct ratios is shown by the plots.

Table 4. Analog set for the coproduct ratios used in text example (based on a search for the value "Lacustrine" within the Source Rock Depositional System variable and the value "Types I and II" within the Kerogen Type variable)

\begin{tabular}{ll}
\hline & Assessment Unit Number and Name \\
\hline 11740201 & Pre-Upper Jurassic \\
31150101 & Upper Paleozoic/Lower Mesozoic Nonmarine Coarse Clastics \\
31270101 & Tertiary Lacustrine \\
31270102 & Pre-Tertiary Buried Hills \\
31280101 & Jurassic/Triassic Fluvial and Lacustrine Sandstone \\
31420201 & Jurassic Lacustrine \\
31440101 & Subtle Traps \\
31440102 & Anticlinal \\
31540102 & Kuche (Northern) Foldbelt \\
37030101 & South Malay Lacustrine \\
37030102 & North Malay Lacustrine \\
38080101 & Pematang/Sihapas Siliciclastics \\
38240101 & Sunda/Asri \\
38280101 & South Sumatra \\
60290101 & Western Pre-Aptian Reservoirs \\
60350101 & Late Cretaceous-Tertiary Turbidites \\
60350102 & Cretaceous Carbonates \\
60350103 & Salt Dome Province Tertiary Sandstones \\
60600101 & North Falklands Basin \\
60600201 & South Falklands Basin \\
72030101 & Gabon Subsalt \\
72030301 & Central Congo Delta and Carbonate Platform \\
&
\end{tabular}




\section{Lacustrine, Types I and II}

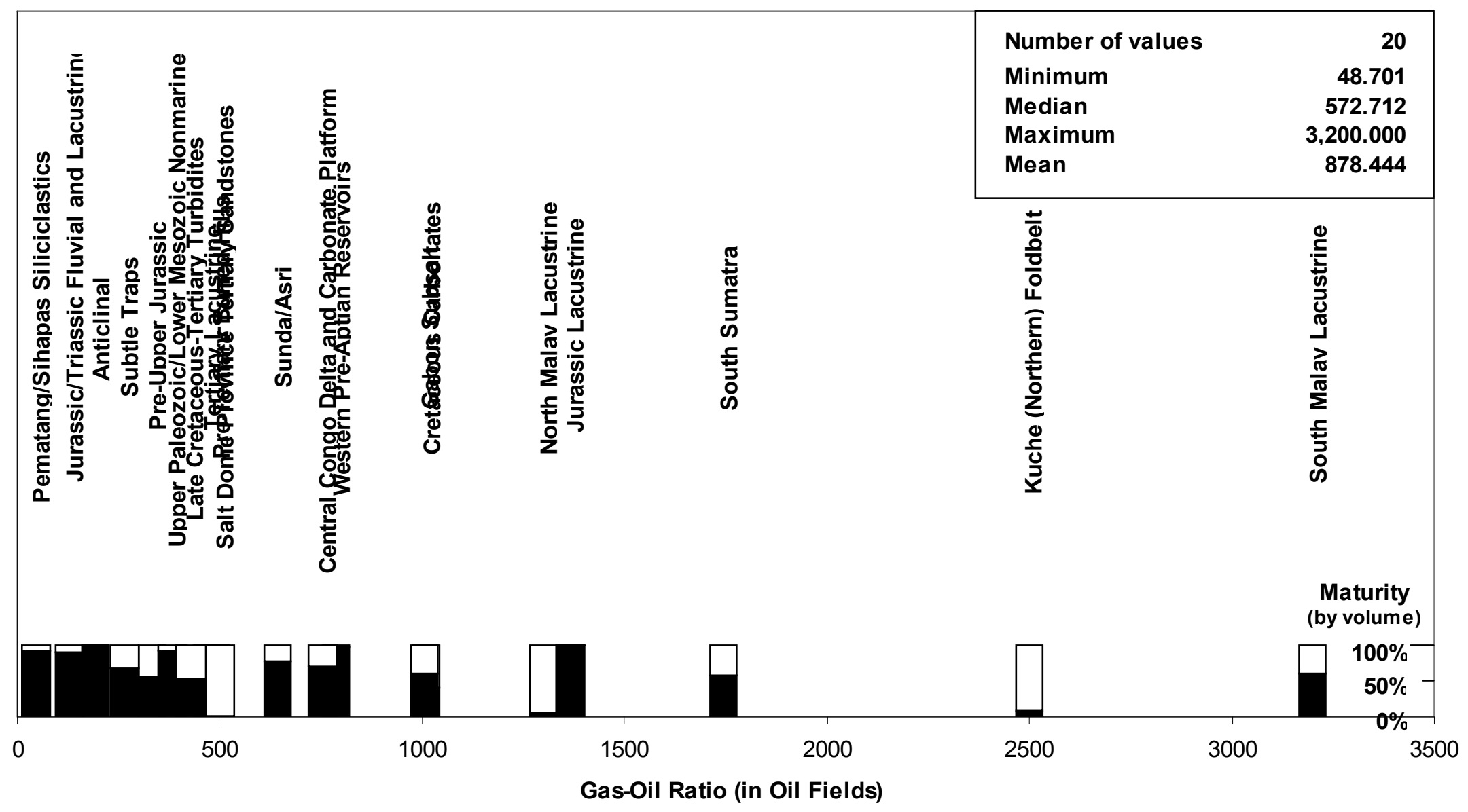

Figure 9. Plot of gas-oil ratio in oil fields for example given in text. 


\section{Lacustrine, Types I and II}

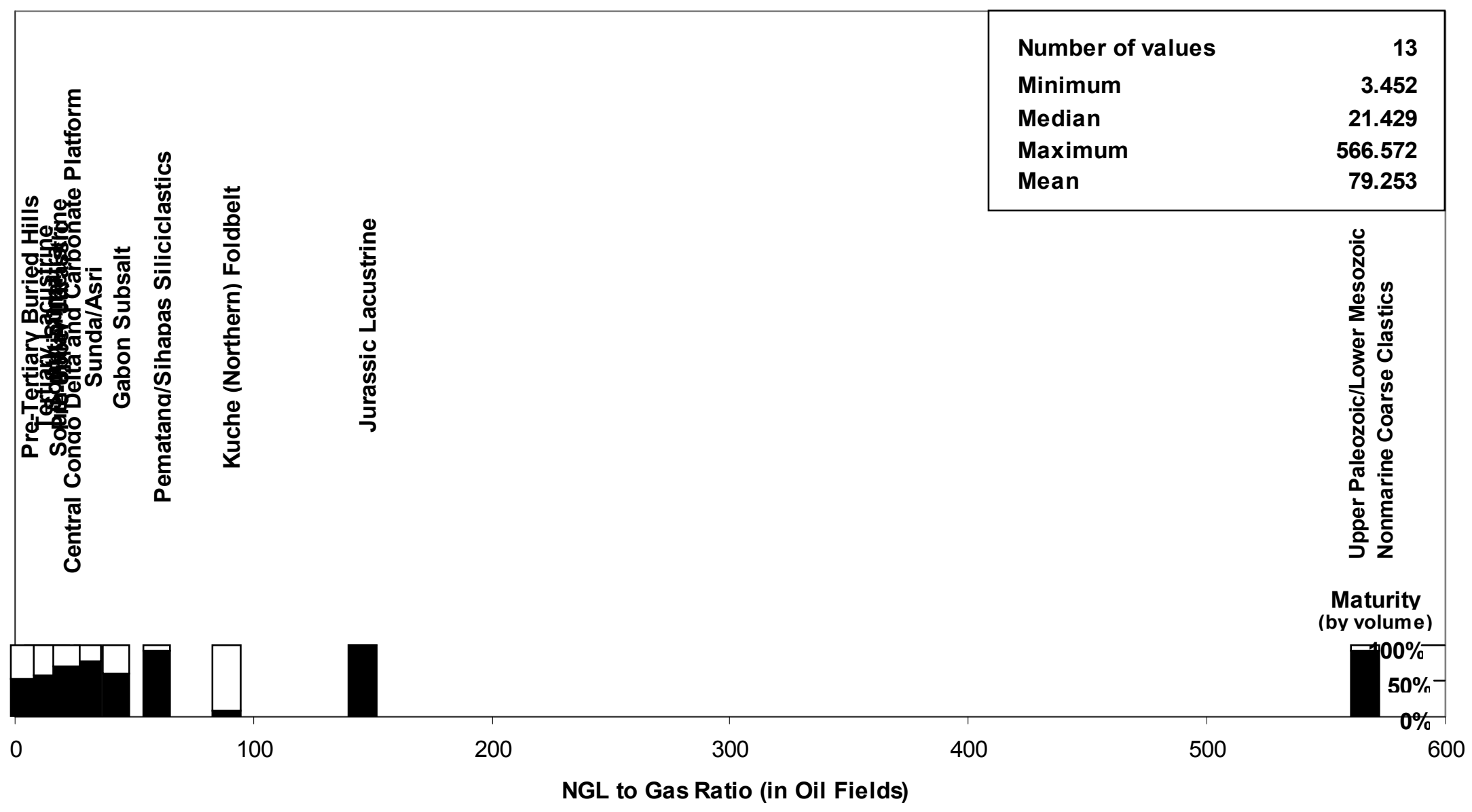

Figure 10. Plot of natural gas liquids (NGL) to gas ratio in oil fields for example given in text. 


\section{Lacustrine, Types I and II}

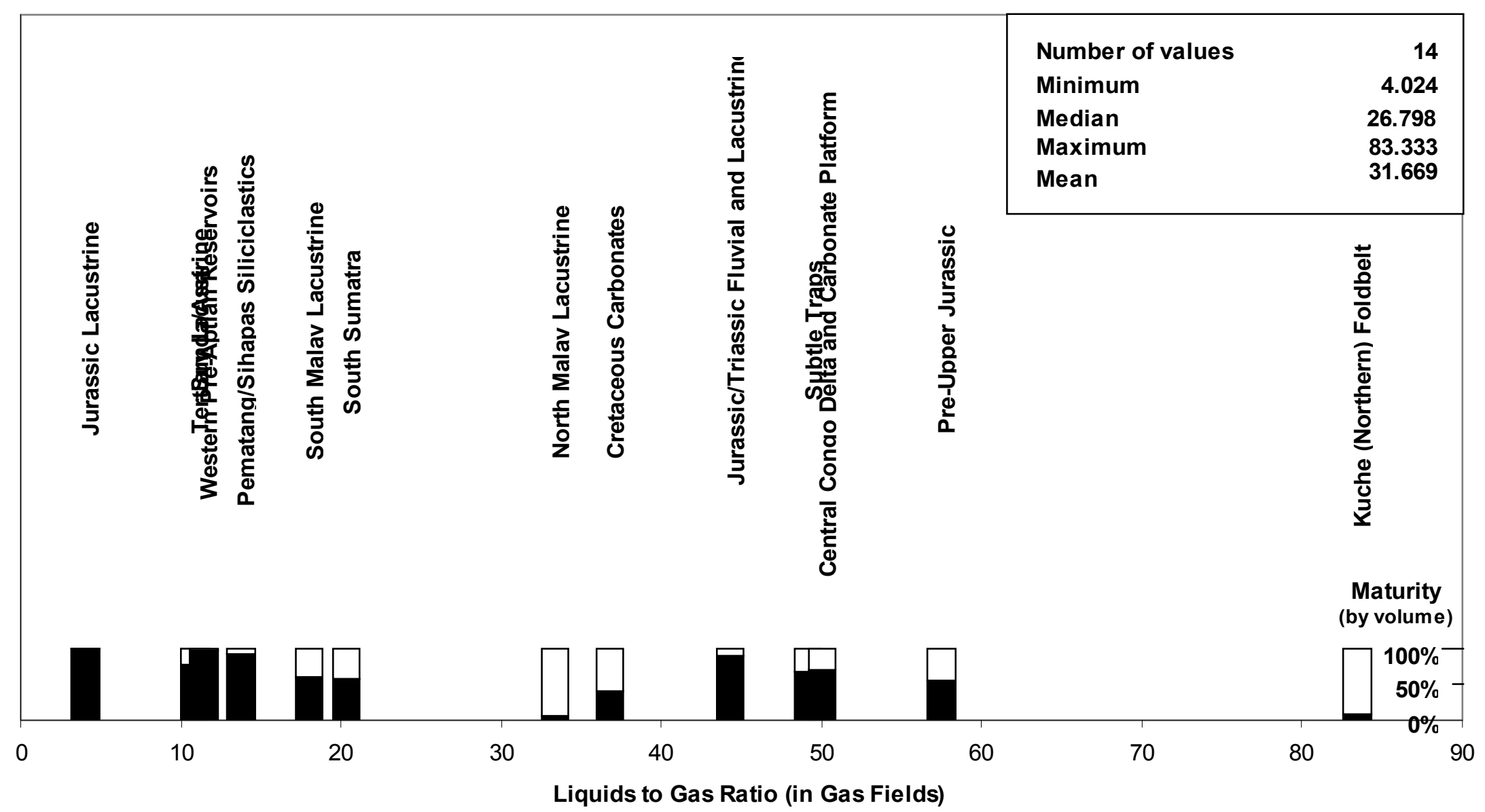

Figure 11. Plot of liquids to gas ratio in gas fields for example given in text. 
The input form (fig. 5) requires an estimate of uncertainty of the mean values for each ratio. The calculated mean values for each coproduct ratio in this analog set are given in the text box. These means might be modified after considering whether to include some of the outlier values, such as the very high value for NGL to gas ratio (fig. 10).

\section{References}

Attanasi, E.D., and Charpentier, R.R., 2002, Comparison of two probability distributions used to model sizes of undiscovered oil and gas accumulations - Does the tail wag the assessment?: Mathematical Geology, v. 34, no. 6, p. 767-777.

Attanasi, E.D., and Charpentier, R.R., 2007, A program for partitioning shifted truncated lognormal distributions into size-class bins: U.S. Geological Survey Open-File Report 2007-1260, 16 p.

Drew, L.J., 1990, Oil and gas forecasting-Reflections of a petroleum geologist: New York, Oxford University Press, 252 p.

Drew, L.J., Schuenemeyer, J.H., and Bawiec, W.J., 1982, Estimation of the future rates of oil and gas discoveries in the western Gulf of Mexico: U.S. Geological Survey Professional Paper 1252, $26 \mathrm{p}$.

Gautier, D.L., Dolton, G.L., Takahashi, K.I., and Varnes, K.L., eds., 1995 National assessment of United States oil and gas resources-Results, methodology, and supporting data: U.S. Geological Survey Digital Data Series 30, one CD-ROM.

Houghton, J.C., 1988, Use of the truncated shifted Pareto distribution in assessing size distribution of oil and gas fields: Mathematical Geology, v. 20, no. 8, p. 907-937.

IHS Energy, Inc, 2004, IHS Energy exploration and production database: Houston, Texas, IHS Energy, Inc; database available from IHS Energy, Inc, P.O. Box 740619, Houston, Texas 77274-0619 U.S.A.

Kaufman, G.M., 1993, Statistical issues in the assessment of undiscovered oil and gas resources: Energy Journal, v. 14, no. 1, p. 183-215.

Klett, T.R., Schmoker, J.W., Charpentier, R.R., Ahlbrandt, T.S., and Ulmishek, G.F., 2000, Glossary, chap. GL of U.S. Geological Survey World Energy Assessment Team, U.S. Geological Survey World Petroleum Assessment 2000-Description and Results: U.S. Geological Survey Digital Data Series 60, 8 p. 
NRG Associates, 1995, The significant oil and gas pools of Canada data base: Colorado Springs, Colorado, NRG Associates, Inc; database available from NRG Associates, Inc, P.O. Box 1655, Colorado Springs, Colorado 80901 U.S.A.

Root, D.H., and Attanasi, E.D., 1993, Small fields in the National Oil and Gas Assessment: American Association of Petroleum Geologists Bulletin, v. 77, no. 3, p. 485-490.

Rose, P.R., 1994, Chance of success and its use in petroleum exploration, in Steinmetz, R., ed., The business of petroleum exploration: American Association of Petroleum Geologists, Treatise of Petroleum Geology, Handbook of Petroleum Geology, v. 2, p. 71-85.

Schmoker, J.W., and Klett, T.R., 2000, U.S. Geological Survey assessment model for undiscovered conventional oil, gas, and NGL resources - The seventh approximation, chap. AM of U.S. Geological Survey World Energy Assessment Team, ed., U.S. Geological Survey World Petroleum Assessment 2000—Description and results: U.S. Geological Survey Digital Data Series DDS-60, p. 1-18.

Schuenemeyer, J.H., and Drew, L.J., 1983, A procedure to estimate the parent population of the size of oil and gas fields as revealed by a study of economic truncation: Journal of the International Association for Mathematical Geology, v. 15, no. 1, p. 145-161.

U.S. Geological Survey World Energy Assessment Team, 2000, U.S. Geological Survey World Petroleum Assessment 2000-Description and Results: U.S. Geological Survey Digital Data Series 60, four CD-ROMs. 


\section{Appendix 1. 1995 Methodology for Small-Field Extrapolation}

In the 1995 U.S. National Oil and Gas Assessment (Gautier and others, 1995), a Pareto distribution was used to describe the size distribution of the set of undiscovered fields larger than 1 million barrels of oil equivalent (MMBOE) in each play. After aggregating to the province level and adding the set of discovered fields, a separate Pareto distribution was used to describe the population of large fields (discovered plus undiscovered) plus small fields. This second Pareto distribution was estimated using binned field sizes (table 1) and the log-geometric distribution (the binned equivalent of the Pareto distribution).

\section{For the Pareto Distribution:}

$f(x)=\frac{\beta L^{\beta}}{x^{(\beta+1)}}=\beta L^{\beta} x^{(-\beta-1)}$

where:

$$
\begin{aligned}
& \mathrm{L}=\text { location parameter (minimum field size) and } \\
& \beta=\text { shape factor }(\beta>0)
\end{aligned}
$$

The proportion of the population between size $\mathrm{L}$ (the minimum) and size $\mathrm{X}$ is:

$$
\begin{aligned}
& F(X)=\int_{L}^{X} f(x) d x=\left[\beta L^{\beta} \frac{X^{(-\beta-1+1)}}{-\beta-1+1}\right]-\left[\beta L^{\beta} \frac{L^{(-\beta-1+1)}}{-\beta-1+1}\right] \\
& F(X)=\left[-\frac{L^{\beta}}{X^{\beta}}\right]-\left[-\frac{L^{\beta}}{L^{\beta}}\right] \\
& F(X)=1-\frac{L^{\beta}}{X^{\beta}}
\end{aligned}
$$

Thus, appropriately, $\mathrm{F}(\mathrm{X})$ equals 0 where $\mathrm{X}=\mathrm{L}$ and approaches 1 as $\mathrm{X}$ goes to infinity. 
The proportion of fields larger than size X would be:

$$
1-F(X)=1-\left[1-\frac{L^{\beta}}{X^{\beta}}\right]=\frac{L^{\beta}}{X^{\beta}}
$$

\section{Relation Between Pareto and Log-Geometric Distributions}

Distribute a Pareto distribution among bins that have limits of $\mathrm{X}, \mathrm{PX}, \mathrm{P}^{2} \mathrm{X}, \mathrm{P}^{3} \mathrm{X}$, and so on. Traditionally, the USGS uses a $P$ of 2 with a starting value of $X=1 \mathrm{MMBOE}$, giving bin limits of 1, 2, 4, 8, and so on (table 1).

The proportion of the population between $\mathrm{X}$ and PX is:

$$
\begin{aligned}
& F(X)=\int_{X}^{P X} f(x) d x=\left\lfloor-\frac{L^{\beta}}{(P X)^{\beta}}\right\rfloor-\left\lfloor-\frac{L^{\beta}}{(X)^{\beta}}\right\rfloor \\
& F(X)=\frac{L^{\beta}}{X^{\beta}}\left[1-\frac{1}{P^{\beta}}\right\rfloor
\end{aligned}
$$

Similarly, the proportion of the population between $\mathrm{PX}$ and $\mathrm{P}^{2} \mathrm{X}$ is:

$$
\begin{aligned}
& F(X)=\int_{P X}^{P^{2} X} f(x) d x=\left\lfloor-\frac{L^{\beta}}{\left(P^{2} X\right)^{\beta}}\right\rfloor-\left[-\frac{L^{\beta}}{(P X)^{\beta}}\right] \\
& F(X)=\frac{L^{\beta}}{X^{\beta}}\left[\frac{1}{P^{\beta}}-\frac{1}{P^{2 \beta}}\right]
\end{aligned}
$$

Also, the proportion of the population between $\mathrm{P}^{2} \mathrm{X}$ and $\mathrm{P}^{3} \mathrm{X}$ is:

$$
F(X)=\int_{P^{2} X}^{P^{3} X} f(x) d x=\left\lfloor-\frac{L^{\beta}}{\left(P^{3} X\right)^{\beta}}\right\rfloor-\left\lfloor-\frac{L^{\beta}}{\left(P^{2} X\right)^{\beta}}\right\rfloor
$$




$$
F(X)=\frac{L^{\beta}}{X^{\beta}}\left[\frac{1}{P^{2 \beta}}-\frac{1}{P^{3 \beta}}\right]
$$

For a binned distribution to be log-geometric, the ratios of frequencies (or proportions) between adjacent bins should be constant.

Let $r_{1}$ be the ratio between the proportion in bin X-PX to that in bin $\mathrm{PX}-\mathrm{P}^{2} \mathrm{X}$ :

$$
r_{1}=\frac{\frac{L^{\beta}}{X^{\beta}}\left[1-\frac{1}{P^{\beta}}\right]}{\frac{L^{\beta}}{X^{\beta}}\left[\frac{1}{P^{\beta}}-\frac{1}{P^{2 \beta}}\right]}=\frac{1-\frac{1}{P^{\beta}}}{\frac{1}{P^{\beta}}-\frac{1}{P^{2 \beta}}}
$$

Multiplying numerator and denominator by $P^{\beta}$ :

$$
r_{1}=\frac{P^{\beta}-1}{1-\frac{1}{P^{\beta}}}
$$

Let $r_{2}$ be the ratio between the proportion in bin $\mathrm{PX}-\mathrm{P}^{2} \mathrm{X}$ to that in $\operatorname{bin} \mathrm{P}^{2} \mathrm{X}-\mathrm{P}^{3} \mathrm{X}$ :

$$
r_{2}=\frac{\frac{L^{\beta}}{X^{\beta}}\left[\frac{1}{P^{\beta}}-\frac{1}{P^{2 \beta}}\right]}{\frac{L^{\beta}}{X^{\beta}}\left[\frac{1}{P^{2 \beta}}-\frac{1}{P^{3 \beta}}\right]}=\frac{\frac{1}{P^{\beta}}-\frac{1}{P^{2 \beta}}}{\frac{1}{P^{2 \beta}}-\frac{1}{P^{3 \beta}}}
$$

Multiplying numerator and denominator by $P^{2 \beta}$ :

$$
r_{2}=\frac{P^{\beta}-1}{1-\frac{1}{P^{\beta}}}
$$

Because $r_{1}=r_{2}$, the binned distribution is log-geometric. 
Upon examining these $\mathrm{r}$ values for actual data sets in the Permian Basin of the United States, Drew and others (1982) and Drew (1990) concluded that field-size distributions were Pareto. They noted a pattern such as that shown in figure 12, drawn from data for the SupraDomanik Carbonates/Clastics Assessment Unit in the analog database. For field-size classes larger than about $200 \mathrm{MMBOE}$, the numbers of fields in each class are small and the ratios of adjacent classes are unstable. For classes smaller than 200 MMBOE, however, the ratio becomes more stable and approaches a constant of approximately 1.4. This implies a loggeometric distribution for the binned data and thus a Pareto distribution for the field sizes themselves. 


\section{Supra-Domanik Carbonates/Clastics}

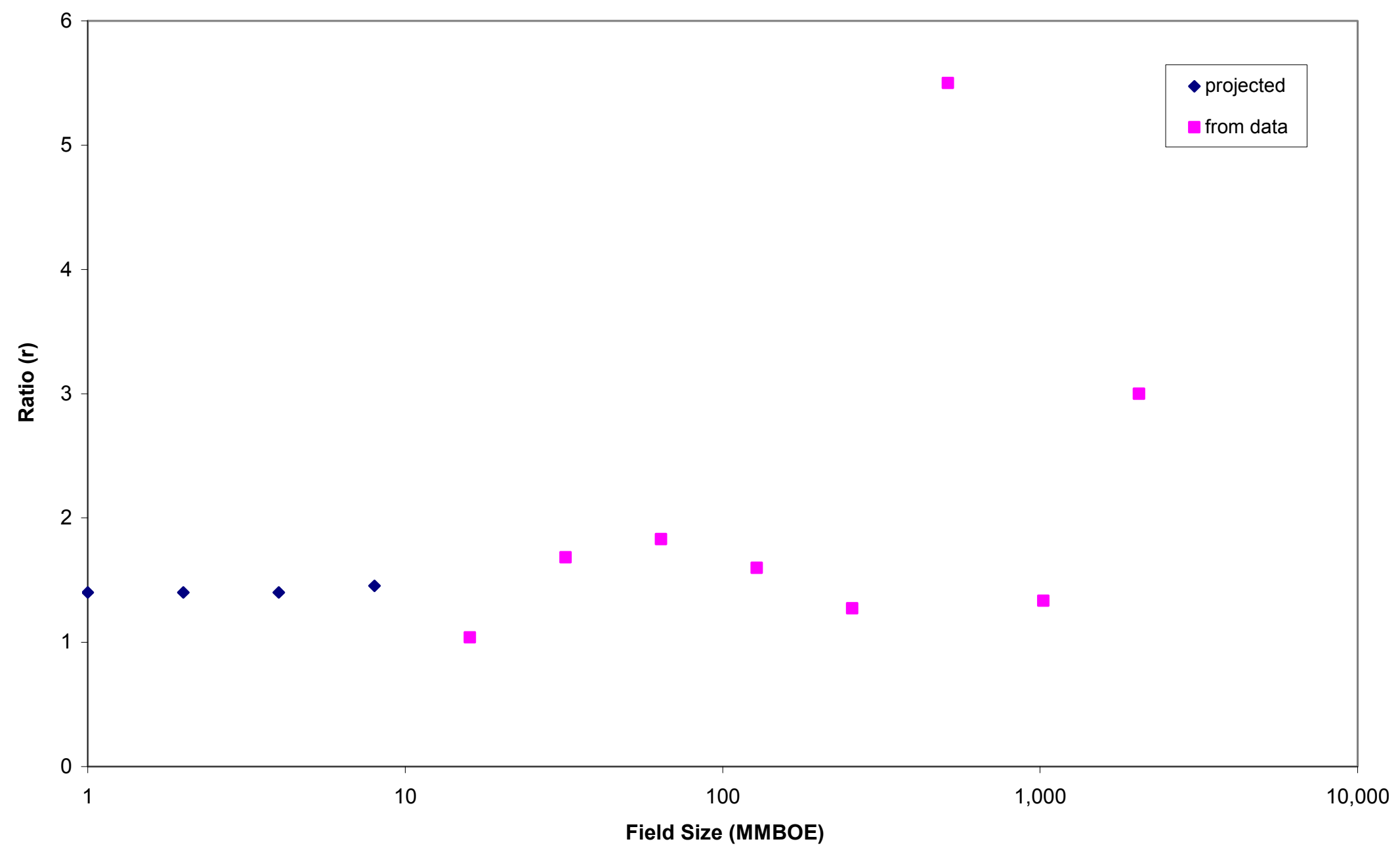

Figure 12. Ratio $(r)$ between the numbers of discovered plus undiscovered fields in adjacent size classes for the Supra-Domanik Carbonates/Clastics Assessment Unit (10150101) of the Volga-Ural Basin, Russia. MMBOE, million barrels of oil equivalent. 
Closer examination of these patterns using the analog database shows that the pattern is not always so clear (fig. 13). In some cases there is little convergence and in others the r's tend to converge on a value greater than 2 . This is problematic because an $r$ value greater than 2 implies that the resource approaches infinity as smaller and smaller size bins are considered. At an $r$ value of 2, each bin has the same volume of resource. 


\section{Central Sirte Carbonates}

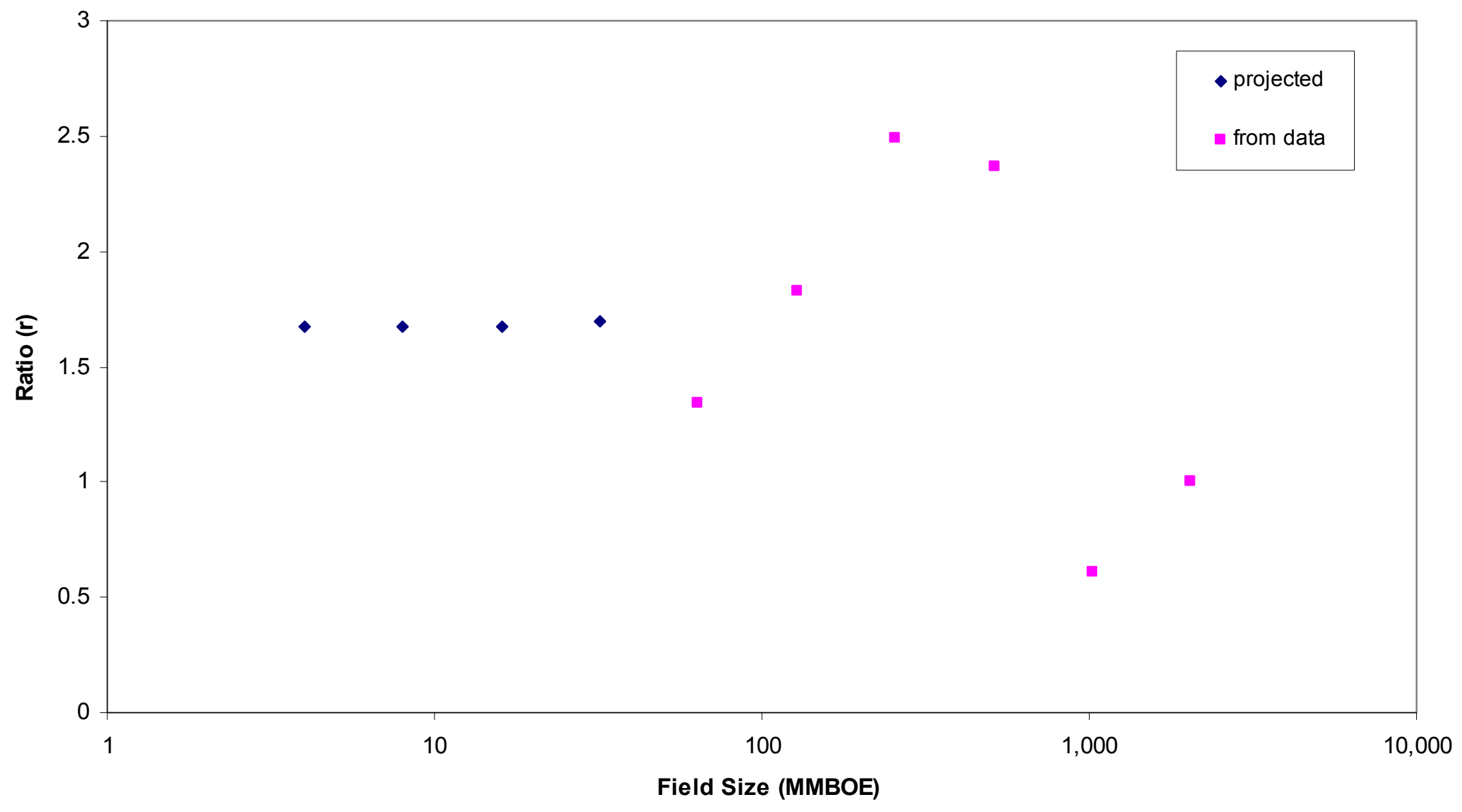

Figure 13. Ratio $(r)$ between the numbers of discovered plus undiscovered fields in adjacent size classes for the Central Sirte Carbonates Assessment Unit (20430102) of the Sirte Basin, Libya. MMBOE, million barrels of oil equivalent. 
In the 1995 U.S. National Oil and Gas Assessment, $r$ was calculated for each of the 58 U.S. provinces with resource potential. Data on discovered oil and gas fields were binned by barrels of oil equivalent (BOE) (table 1). The Pareto distributions for undiscovered fields were divided into bins. This was the raw data set used for the calculation. The five size classes from class 7 (2 to $4 \mathrm{MMBOE}$ ) to class 11 (32 to $64 \mathrm{MMBOE}$ ) were used in the calculation. Class 6 (1 to $2 \mathrm{MMBOE}$ ) was not used because of partial economic truncation at that size range.

A least squares procedure was used to calculate a best-fit value for $r$. The number of fields in size classes 7 through 11 is:

$$
N=\sum_{c=7}^{c=11} n_{c}
$$

where $\mathrm{n}_{\mathrm{c}}$ is the number of discovered fields plus the estimated mean value of number of undiscovered fields in class $\mathrm{c}$.

If the distribution were log-geometric with ratio $r$ :

Class 11 would have some number $\mathrm{n}_{11}$ of fields, Class 10 would have $\mathrm{r}_{11}$ of fields, Class 9 would have $\mathrm{r}^{2} \mathrm{n}_{11}$ of fields, Class 8 would have $\mathrm{r}^{3} \mathrm{n}_{11}$ of fields, and Class 7 would have $\mathrm{r}^{4} \mathrm{n}_{11}$ of fields.

Thus, the total number of fields in classes 7 to 11 would be:

$$
N=\left(r^{4} n\right)+\left(r^{3} n\right)+\left(r^{2} n\right)+(r n)+n
$$
class by:

Given a trial value for $r=r_{\text {trial }}$, one can calculate expected values of numbers in each size

$$
\begin{aligned}
& n_{11 \text { exp }}=\frac{N}{\left(r_{\text {trial }}^{4}+r_{\text {trial }}^{3}+r_{\text {trial }}^{2}+r_{\text {trial }}+1\right)} \\
& n_{10 \text { exp }}=\frac{r_{\text {trial }} N}{\left(r_{\text {trial }}^{4}+r_{\text {trial }}^{3}+r_{\text {trial }}^{2}+r_{\text {trial }}+1\right)} \\
& n_{9 \exp }=\frac{r_{\text {trial }}^{2} N}{\left(r_{\text {trial }}^{4}+r_{\text {trial }}^{3}+r_{\text {trial }}^{2}+r_{\text {trial }}+1\right)}
\end{aligned}
$$




$$
\begin{aligned}
& n_{8 \exp }=\frac{r_{\text {trial }}^{3} N}{\left(r_{\text {trial }}^{4}+r_{\text {trial }}^{3}+r_{\text {trial }}^{2}+r_{\text {trial }}+1\right)} \\
& n_{7 \exp }=\frac{r_{\text {trial }}^{4} N}{\left(r_{\text {trial }}^{4}+r_{\text {trial }}^{3}+r_{\text {trial }}^{2}+r_{\text {trial }}+1\right)}
\end{aligned}
$$

The expected value (given some trial $r$ ) of number of fields in each of the five size classes was compared to the number of discovered plus estimated undiscovered from the assessment and the sum of squared deviations calculated:

$$
S S Q=\left(n_{11}-n_{11 \exp }\right)^{2}+\left(n_{10}-n_{10 \exp }\right)^{2}+\left(n_{9}-n_{9 \exp }\right)^{2}+\left(n_{8}-n_{8 \exp }\right)^{2}+\left(n_{7}-n_{7 \exp }\right)^{2}
$$

A sum of squared deviations from the expected was calculated for each value from 1.4 to 1.7 at 0.01 intervals $(1.40,1.41,1.42 \ldots 1.69,1.70)$. The trial value of $r$ with the least sum of square deviations was chosen as $r$ for the province.

Checks were conducted for data that did not fit the extrapolated field size. In some cases the number of discovered fields in one of classes 1 to 6 was larger than that estimated from the small-field extrapolation procedure. In this case, the extrapolated number of fields was used rather than the actual number of discovered fields.

\section{Changes to Small-Field Extrapolation Methodology}

For the 1995 U.S. National Oil and Gas Assessment, small oil and gas fields were estimated at the province level only. For the analog database a similar methodology was applied at the assessment unit level. Because of the smaller numbers of fields for each assessment unit there was an increased chance of poor distribution fit. Checks were thus made for cases where there were more discovered fields than the extrapolation estimated in the small field-size classes. In such cases, the additional discovered fields were eliminated and the database cell was colored gold in the Oil Bins, Gas Bins, and BOE Bins worksheets.

The WPA 2000 used a shifted truncated lognormal distribution rather than a Pareto distribution for assessing large undiscovered fields. It also used a variable minimum assessed field size. Both of these changes made modification to the procedure necessary. In the 1995 methodology, the minimum size assessed was 1 MMBOE. Because a Pareto distribution was used, the modal bin was always the 1 to $2 \mathrm{MMBOE}$ class (class 6). The five bins used for calculation of $r$ were the five starting with the 2 to 4 MMBOE class (class 7) up through the 32 to $64 \mathrm{MMBOE}$ class (class 11). In the present procedure, the modal bin may be somewhere above the minimum assessed size (fig. 14). The five bins above the modal bin are used for the calculation of $\mathrm{r}$ (fig. 15). 


\section{Main Basin Platform of Timan-Pechora Basin}

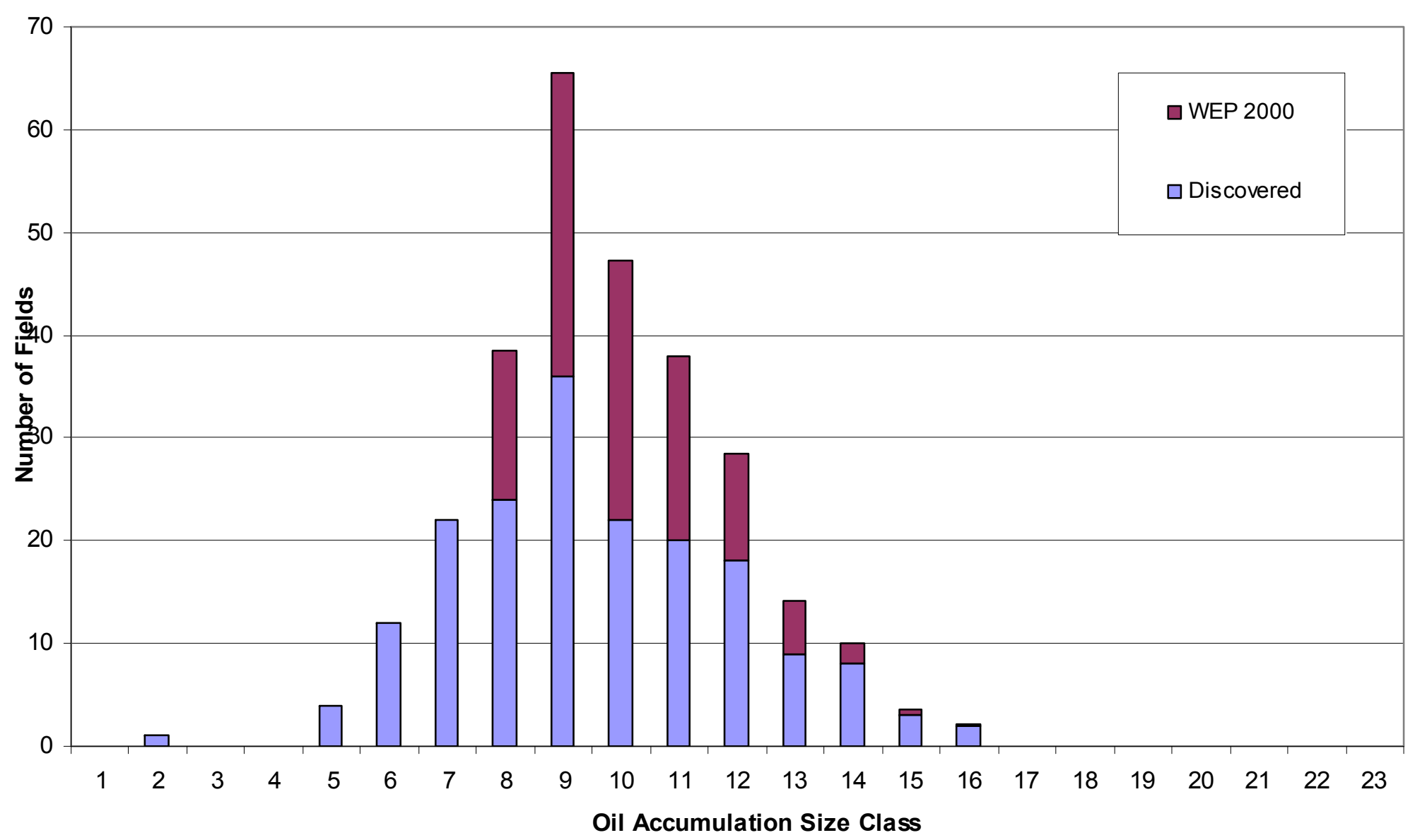

Figure 14. Numbers of discovered and undiscovered (from the 2000 USGS assessment) oil fields by size class in the Main Basin Platform Assessment Unit (10080102) of the Timan-Pechora Basin, Russia. Note the linear vertical scale. 


\section{Main Basin Platform of Timan-Pechora Basin}

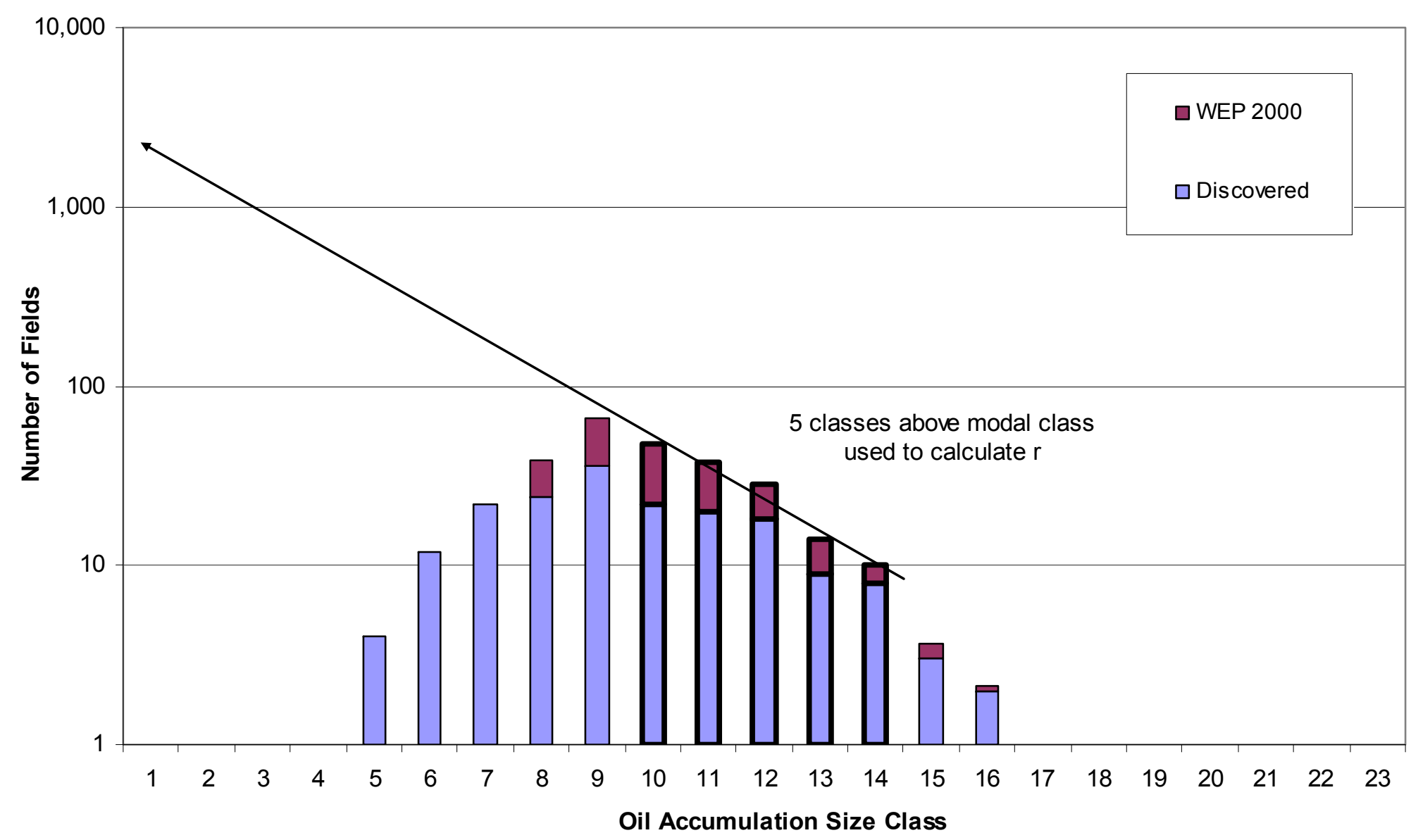

Figure 15. Numbers of discovered and undiscovered (from the 2000 USGS assessment) oil fields by size class in the Main Basin Platform Assessment Unit (10080102) of the Timan-Pechora Basin, Russia, showing an extrapolation of small-field sizes using the data from classes 10 to 14. Note the logarithmic vertical scale. 
The mean size of fields within a size class can be calculated for a lognormal or a Pareto distribution. The size distributions in the analog database, however, are combinations of a lognormal distribution and additional discrete (discovered) fields. As a first approximation, the 1995 methodology used a mean size of 1.5 times the lower size-class boundary (half-way between the two bounds of the size class).

In experiments with lognormal distributions, it can be shown that the mean size in each field size class varies in location from class to class (table 5). Below the mode of the field-size distribution, the mean size of a class is closer to the upper boundary of the size class. At the mode, the mean size of a class is approximately at the center of the size class. Above the mode, the mean size of a class is closer to the lower boundary and approaches the lower boundary even more closely as one goes to larger size classes. One can specify the mean size of a class by using a multiplier between 1 and 2 times the lower size-class boundary. Use of different values for that multiplier per size class would have greatly complicated the calculations for the database because the multiplier values depend not only on the size class but also on the distribution itself. Experiments showed that a multiplier value of 1.38 times the lower size class boundary gave the best approximation if only one value was to be used. The new methodology thus uses the value of 1.38 , rather than the 1.5 that was used in 1995 . 
Table 5. Simulation of a lognormal distribution with mean of 50 million barrels of oil equivalent (MMBOE) and standard deviation of $100 \mathrm{MMBOE}$ divided into USGS field-size classes. Right column shows relation of the mean in each class relative to the class boundaries.

\begin{tabular}{|c|c|c|c|c|c|}
\hline Class & Minimum size & Number & Volume & Mean size & Mean size/Minimum \\
\hline 1 & 0.03125 & 1 & 0.06 & 0.06 & 1.88 \\
\hline 2 & 0.0625 & 27 & 2.93 & 0.11 & 1.74 \\
\hline 3 & 0.125 & 151 & 31.04 & 0.21 & 1.64 \\
\hline 4 & 0.25 & 1,173 & 466.55 & 0.40 & 1.59 \\
\hline 5 & 0.5 & 5,665 & $4,422.19$ & 0.78 & 1.56 \\
\hline 6 & 1 & 21,401 & $32,905.38$ & 1.54 & 1.54 \\
\hline 7 & 2 & 59,212 & $179,567.86$ & 3.03 & 1.52 \\
\hline 8 & 4 & 121,337 & $724,043.50$ & 5.97 & 1.49 \\
\hline 9 & 8 & 186,682 & $2,192,422.75$ & 11.74 & 1.47 \\
\hline 10 & 16 & 215,607 & $4,976,658.55$ & 23.08 & 1.44 \\
\hline 11 & 32 & 185,660 & $8,425,796.98$ & 45.38 & 1.42 \\
\hline 12 & 64 & 118,833 & $10,603,253.55$ & 89.23 & 1.39 \\
\hline 13 & 128 & 56,751 & $9,961,970.76$ & 175.54 & 1.37 \\
\hline 14 & 256 & 20,621 & $7,111,576.20$ & 344.87 & 1.35 \\
\hline 15 & 512 & 5,545 & $3,768,982.60$ & 679.71 & 1.33 \\
\hline 16 & 1024 & 1,148 & $1,535,004.65$ & $1,337.11$ & 1.31 \\
\hline 17 & 2048 & 166 & $443,442.94$ & $2,671.34$ & 1.30 \\
\hline 18 & 4096 & 19 & $106,505.41$ & $5,605.55$ & 1.37 \\
\hline 19 & 8192 & 0 & 0.00 & 0.00 & 0.00 \\
\hline 20 & 16384 & 0 & 0.00 & 0.00 & 0.00 \\
\hline 21 & 32768 & 0 & 0.00 & 0.00 & 0.00 \\
\hline Totals: & & 999,999 & $50,067,054$ & 50.07 & \\
\hline
\end{tabular}

Sizes and volumes in millions of barrels equivalent 


\section{Sensitivity Tests}

A series of sensitivity tests was conducted to determine the effect of different assumptions on the calculation of $\mathrm{r}$. The main assumptions are listed in table 6 and the results of the sensitivity analysis on several of these assumptions are given in table 7. Given the basic framework of accepting assumption 1, the tests determined that most of the assumptions were not particularly sensitive. The main exception was assumption 2 , the constraint that $r$ is constrained to lie between 1.4 and 1.7 .

Table 6. Assumptions for the 1995 small-field assessment methodology.

1. The small fields have a log-geometric distribution.

2. $\quad r$ can vary from 1.4 to 1.7 .

3. A least-squares procedure should be used to calculate $r$.

4. Mean size in a bin is 1.5 times the lower bin limit.

5. The least-squares procedure should not use bins with value less than 1.0.

6. $\quad r$ should be fit to BOE totals, not separately for oil and gas fields.

7. The least-squares procedure uses the five bins starting with the one larger than the modal bin.

8. Oil and gas should be proportioned similar to the modal bin plus the next two larger bins.

9. The least-squares fit should not use discovered fields of a type (oil/gas) not assessed.

10. The oil or gas proportion should not use discovered fields of a type (oil/gas) not assessed.

11. "Excess" discovered fields in a bin should be eliminated.

12. Least squares should be based on numbers of accumulations rather than volumes of resources.

13. $r$ should be calculated at the province scale. 
Table 7. Sensitivity studies of the calculation of $r$ given different assumptions.

\begin{tabular}{|c|c|c|c|c|c|c|c|c|c|c|c|c|}
\hline \multicolumn{2}{|c|}{ assessment unit number and name } & \multirow{2}{*}{\begin{tabular}{|c|}
$\begin{array}{c}\text { base } \\
\text { case } \mathbf{r}\end{array}$ \\
1.70 \\
\end{tabular}} & \multirow{2}{*}{\begin{tabular}{|c|}
$\begin{array}{c}\text { extended } \\
\text { base case }\end{array}$ \\
3.00 \\
\end{tabular}} & \multirow{2}{*}{$\begin{array}{c}\begin{array}{c}\text { multi- } \\
\text { nomial r }\end{array} \\
3.00\end{array}$} & \multirow{2}{*}{$\begin{array}{c}\text { ratio } \\
\mathbf{1} / \mathbf{2} \\
2.56\end{array}$} & \multirow{2}{*}{ 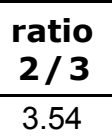 } & \multirow{2}{*}{\begin{tabular}{|c|}
$\begin{array}{r}\text { ratio } \\
\mathbf{3} / \mathbf{4}\end{array}$ \\
4.86 \\
\end{tabular}} & \multirow{2}{*}{\begin{tabular}{|r|}
$\begin{array}{r}\text { ratio } \\
\mathbf{4 / 5}\end{array}$ \\
16.83 \\
\end{tabular}} & \multirow{2}{*}{\begin{tabular}{|c|}
$\begin{array}{c}\text { mean } \\
\text { ratio }\end{array}$ \\
6.95 \\
\end{tabular}} & \multirow{2}{*}{\begin{tabular}{|c|}
$\begin{array}{c}1.4 \\
\text { mean }\end{array}$ \\
3.00 \\
\end{tabular}} & \multirow{2}{*}{\begin{tabular}{|c|}
$\begin{array}{c}1.38 \\
\text { mean }\end{array}$ \\
3.00 \\
\end{tabular}} & \multirow{2}{*}{$\begin{array}{c}\begin{array}{c}\text { no }<1 \\
\text { constraint }\end{array} \\
3.00\end{array}$} \\
\hline 10080101 & Northwest Izhma-Pechora Depression & & & & & & & & & & & \\
\hline 10080102 & Main Basin Platform & 1.45 & 1.45 & 1.44 & 1.20 & 1.33 & 1.98 & 1.43 & 1.49 & 1.45 & 1.45 & 1.45 \\
\hline 10080103 & Foredeep Basins & 1.70 & 2.22 & 2.20 & 2.17 & 1.99 & 2.44 & 3.03 & 2.41 & 2.22 & 2.22 & 2.22 \\
\hline 10090101 & Carboniferous-Lower Permian Clastics & 1.60 & 1.60 & 1.60 & 1.46 & 1.64 & 1.65 & 1.77 & 1.63 & 1.60 & 1.60 & 1.60 \\
\hline 10090102 & Devonian Synrift & 1.70 & 2.46 & 2.43 & 1.93 & 2.55 & 3.39 & 5.53 & 3.35 & 2.46 & 2.46 & 2.46 \\
\hline 10150101 & Supra-Domanik Carbonates/Clastics & 1.40 & 1.40 & 1.39 & 1.45 & 1.04 & 1.68 & 1.83 & 1.50 & 1.40 & 1.40 & 1.40 \\
\hline 10150102 & Lower Volga & 1.40 & 1.35 & 1.35 & 1.00 & 1.48 & 1.51 & 1.50 & 1.37 & 1.35 & 1.35 & 1.35 \\
\hline 10150103 & Sub-Domanik Devonian Clastics & 1.45 & 1.45 & 1.43 & 1.24 & 1.64 & 0.98 & 3.31 & 1.80 & 1.45 & 1.45 & 1.45 \\
\hline 10150201 & Permian Reefs/Thrust Folds & 1.70 & 1.75 & 1.71 & 1.43 & 1.44 & 1.56 & 134.98 & 34.85 & 1.75 & 1.75 & 1.76 \\
\hline 10160101 & $\begin{array}{l}\text { North and West Margins Subsalt Pinnacle } \\
\text { Reefs }\end{array}$ & 1.70 & 2.36 & 2.33 & 1.93 & 2.33 & 3.13 & 4.69 & 3.02 & 2.36 & 2.36 & 2.36 \\
\hline 10160102 & $\begin{array}{l}\text { North and West Margins Subsalt Barrier } \\
\text { Reefs }\end{array}$ & 1.70 & 3.00 & 3.00 & 3.26 & 32.61 & 0.00 & 0.00 & 17.93 & 3.00 & 3.00 & 3.00 \\
\hline 10160103 & East and Southeast Margins Subsalt & 1.70 & 1.79 & 1.76 & 1.80 & 1.59 & 1.43 & 4.67 & 2.37 & 1.79 & 1.79 & 1.79 \\
\hline 10160104 & South Margin Subsalt & 1.40 & 1.39 & 1.38 & 1.24 & 1.16 & 1.75 & 1.72 & 1.47 & 1.39 & 1.39 & 1.39 \\
\hline 10160106 & Suprasalt & 1.70 & 1.82 & 1.80 & 1.46 & 1.68 & 2.50 & 2.44 & 2.02 & 1.82 & 1.82 & 1.82 \\
\hline 10500101 & Kolguyev Terrace & 1.70 & 2.21 & 2.20 & 1.77 & 2.48 & 2.53 & 3.10 & 2.47 & 2.21 & 2.21 & 2.21 \\
\hline 10500102 & South Barents and Ludlov Saddle & 1.54 & 1.54 & 1.53 & 1.42 & 1.31 & 1.75 & 2.22 & 1.67 & 1.54 & 1.54 & 1.54 \\
\hline 10500103 & North Barents & 1.70 & 1.79 & 1.78 & 1.57 & 1.74 & 1.99 & 2.30 & 1.90 & 1.79 & 1.79 & 1.79 \\
\hline 11080101 & Tertiary Foredeep & 1.68 & 1.68 & 1.71 & 1.45 & 2.50 & 1.67 & 1.01 & 1.66 & 1.68 & 1.68 & 1.68 \\
\hline 11080102 & Foreland Slope & 1.50 & 1.50 & 1.53 & 1.38 & 2.03 & 1.75 & 0.78 & 1.49 & 1.50 & 1.50 & 1.50 \\
\hline 11080103 & Subsalt Jurassic & 1.70 & 2.44 & 2.37 & 2.70 & 1.20 & 7.56 & 4.49 & 3.99 & 2.44 & 2.44 & 2.45 \\
\hline 11090101 & Foldbelt-Foothills & 1.70 & 1.94 & 1.88 & 1.64 & 1.65 & 1.69 & 420.72 & 106.43 & 1.94 & 1.94 & 1.94 \\
\hline 11090102 & Terek-Sunzha Subsalt Jurassic & 1.70 & 3.00 & 3.00 & 2.45 & 3.76 & 5.80 & 0.00 & 4.00 & 3.00 & 3.00 & 3.00 \\
\hline 11090103 & Foreland Slope and Foredeep & 1.70 & 3.00 & 3.00 & 6.42 & 11.54 & 0.00 & 0.00 & 8.98 & 3.00 & 3.00 & 3.00 \\
\hline
\end{tabular}




\begin{tabular}{|c|c|c|c|c|c|c|c|c|c|c|c|c|}
\hline 11090201 & South Mangyshlak (Entire) & 1.70 & 1.74 & 1.74 & 1.25 & 3.82 & 0.74 & 3.21 & 2.26 & 1.74 & 1.74 & 1.74 \\
\hline 11090301 & Offshore Prikumsk Zone & 1.70 & 3.00 & 3.00 & 2.81 & 3.27 & 4.04 & 6.91 & 4.26 & 3.00 & 3.00 & 3.00 \\
\hline 11090302 & Onshore Stavropol-Prikumsk & 1.70 & 1.91 & 1.90 & 1.70 & 1.40 & 5.68 & 1.02 & 2.45 & 1.91 & 1.91 & 1.91 \\
\hline 11090303 & Central Caspian Offshore & 1.70 & 3.00 & 3.00 & 6.07 & 22.60 & 0.00 & 0.00 & 14.34 & 3.00 & 3.00 & 3.00 \\
\hline 11120101 & Apsheron-Pribalkhan Zone & 1.45 & 1.45 & 1.46 & 1.14 & 1.88 & 1.85 & 0.89 & 1.44 & 1.45 & 1.45 & 1.45 \\
\hline 11120102 & $\begin{array}{l}\text { Lower Kura Depression and Adjacent } \\
\text { Shelf }\end{array}$ & 1.46 & 1.46 & 1.45 & 1.38 & 1.33 & 1.31 & 2.62 & 1.66 & 1.46 & 1.46 & 1.46 \\
\hline 11120103 & $\begin{array}{l}\text { Gograndag-Okarem Zone and Adjacent } \\
\text { Shelf }\end{array}$ & 1.64 & 1.64 & 1.65 & 1.34 & 1.91 & 1.84 & 1.49 & 1.65 & 1.64 & 1.64 & 1.64 \\
\hline 11120104 & Central Offshore & 1.70 & 1.75 & 1.74 & 1.41 & 1.71 & 2.09 & 2.56 & 1.94 & 1.75 & 1.75 & 1.75 \\
\hline 11120105 & Iran Onshore/Nearshore & 1.70 & 1.99 & 1.97 & 1.52 & 1.99 & 2.60 & 3.44 & 2.39 & 1.99 & 1.99 & 1.99 \\
\hline 11500101 & Mesozoic Sandstone Reservoirs & 1.70 & 1.87 & 1.87 & 1.51 & 2.20 & 1.89 & 2.28 & 1.97 & 1.87 & 1.87 & 1.87 \\
\hline 11500201 & Jurassic-Tertiary Reservoirs & 1.69 & 1.69 & 1.70 & 1.55 & 1.68 & 3.22 & 0.74 & 1.80 & 1.69 & 1.69 & 1.69 \\
\hline 11500301 & Upper Paleozoic Carbonates & 1.70 & 2.08 & 2.06 & 1.79 & 2.05 & 2.43 & 2.92 & 2.30 & 2.08 & 2.08 & 2.08 \\
\hline 11540101 & Northern and Western Areas & 1.70 & 1.88 & 1.87 & 1.60 & 1.78 & 2.75 & 1.75 & 1.97 & 1.88 & 1.88 & 1.88 \\
\hline 11540102 & Karabil-Badkhyz (Southern Area) & 1.70 & 1.92 & 1.90 & 1.80 & 1.84 & 1.76 & 3.38 & 2.20 & 1.92 & 1.92 & 1.92 \\
\hline 11540103 & Murgab Depression Suprasalt & 1.55 & 1.55 & 1.54 & 0.94 & 1.33 & 3.81 & 1.42 & 1.87 & 1.55 & 1.55 & 1.55 \\
\hline 11540104 & Murgab Depression Subsalt & 1.40 & 1.24 & 1.25 & 1.08 & 2.02 & 0.82 & 1.24 & 1.29 & 1.24 & 1.24 & 1.24 \\
\hline 11740101 & Upper Jurassic-Cretaceous Sandstones & 1.46 & 1.46 & 1.47 & 1.51 & 1.39 & 1.59 & 1.33 & 1.46 & 1.46 & 1.46 & 1.46 \\
\hline 11740201 & Pre-Upper Jurassic & 1.70 & 1.74 & 1.74 & 1.64 & 1.78 & 1.85 & 1.71 & 1.74 & 1.74 & 1.74 & 1.74 \\
\hline 11740301 & Northern West Siberian Onshore Gas & 1.40 & 1.37 & 1.37 & 1.13 & 1.32 & 1.82 & 1.26 & 1.38 & 1.37 & 1.37 & 1.37 \\
\hline 11740302 & South Kara Sea Offshore & 1.40 & 1.40 & 1.39 & 1.15 & 1.47 & 1.32 & 1.99 & 1.48 & 1.40 & 1.40 & 1.40 \\
\hline 12070101 & $\begin{array}{l}\text { Yenisey Foldbelt Riphean-Craton Margin } \\
\text { Riphean }\end{array}$ & 1.61 & 1.61 & 1.62 & 1.31 & 1.94 & 1.87 & 1.28 & 1.60 & 1.61 & 1.61 & 1.61 \\
\hline 12100101 & $\begin{array}{l}\text { Baikal-Patom Foldbelt Riphean-Craton } \\
\text { Margin Vendian }\end{array}$ & 1.55 & 1.55 & 1.55 & 1.29 & 1.43 & 2.48 & 1.22 & 1.61 & 1.55 & 1.55 & 1.55 \\
\hline 13220101 & Onshore and Offshore Northeastern Shelf & 1.64 & 1.64 & 1.65 & 1.16 & 2.30 & 1.79 & 1.40 & 1.66 & 1.64 & 1.64 & 1.64 \\
\hline 20040101 & Ma'Rib-Al Jawf/Shabwah/Masila & 1.70 & 1.80 & 1.78 & 1.47 & 1.46 & 3.38 & 1.88 & 2.05 & 1.80 & 1.80 & 1.80 \\
\hline 20140101 & Ghaba-Makarem Combined Structural & 1.54 & 1.54 & 1.52 & 1.29 & 1.10 & 2.45 & 2.50 & 1.83 & 1.54 & 1.54 & 1.54 \\
\hline 20160101 & Fahud-Huqf Combined Structural & 1.70 & 2.15 & 2.19 & 2.50 & 2.95 & 1.31 & 1.47 & 2.06 & 2.15 & 2.15 & 2.15 \\
\hline 20160201 & Natih-Fiqa Structural/Stratigraphic & 1.40 & 1.28 & 1.31 & 1.02 & 2.24 & 2.13 & 0.37 & 1.44 & 1.28 & 1.28 & 1.28 \\
\hline 20190101 & $\begin{array}{l}\text { Cretaceous Reservoirs in Northwest } \\
\text { Desert Anticlines }\end{array}$ & 1.40 & 1.28 & 1.28 & 1.33 & 1.08 & 1.70 & 1.07 & 1.30 & 1.28 & 1.28 & 1.28 \\
\hline
\end{tabular}




\begin{tabular}{|c|c|c|c|c|c|c|c|c|c|c|c|c|}
\hline 20190102 & $\begin{array}{l}\text { Cretaceous Reservoirs in South Gulf } \\
\text { Suprasalt Structural }\end{array}$ & 1.50 & 1.50 & 1.47 & 1.26 & 1.00 & 2.19 & 3.31 & 1.94 & 1.50 & 1.50 & 1.50 \\
\hline 20190103 & $\begin{array}{l}\text { Mesozoic/Tertiary Foredeep Fold and } \\
\text { Thrust }\end{array}$ & 1.69 & 1.69 & 1.72 & 1.33 & 2.05 & 4.44 & 0.46 & 2.07 & 1.69 & 1.69 & 1.69 \\
\hline 20190201 & $\begin{array}{l}\text { Jurassic Reservoirs in Northwest Desert } \\
\text { Anticlines }\end{array}$ & 1.52 & 1.52 & 1.51 & 0.97 & 1.70 & 1.65 & 2.79 & 1.78 & 1.52 & 1.52 & 1.52 \\
\hline 20190202 & $\begin{array}{l}\text { Jurassic Reservoirs in South Gulf } \\
\text { Suprasalt/Qatar Arch Structural }\end{array}$ & 1.60 & 1.60 & 1.61 & 1.54 & 1.78 & 1.69 & 1.28 & 1.57 & 1.60 & 1.60 & 1.60 \\
\hline 20190301 & Khuff Carbonates in Salt Structures & 1.70 & 1.81 & 1.79 & 1.59 & 1.45 & 2.70 & 2.56 & 2.07 & 1.81 & 1.81 & 1.81 \\
\hline 20190302 & Paleozoic Reservoirs & 1.40 & 1.36 & 1.36 & 1.27 & 1.30 & 1.42 & 1.57 & 1.39 & 1.36 & 1.36 & 1.36 \\
\hline 20210101 & $\begin{array}{l}\text { Central Arch Horst-Block Anticlinal Oil and } \\
\text { Gas }\end{array}$ & 1.70 & 1.93 & 1.92 & 1.45 & 2.11 & 2.18 & 3.42 & 2.29 & 1.93 & 1.93 & 1.93 \\
\hline 20210102 & North Gulf Salt Basin Structural Gas & 1.51 & 1.51 & 1.52 & 1.37 & 1.69 & 1.61 & 1.32 & 1.50 & 1.51 & 1.51 & 1.51 \\
\hline 20210201 & Horst-Block Anticlinal Oil & 1.66 & 1.66 & 1.63 & 1.31 & 1.08 & 2.92 & 6.29 & 2.90 & 1.66 & 1.66 & 1.67 \\
\hline 20210202 & Salt-Involved Structural Oil & 1.56 & 1.56 & 1.61 & 1.63 & 1.74 & 7.08 & 0.18 & 2.66 & 1.56 & 1.56 & 1.57 \\
\hline 20230101 & Horst/Graben-Related Oil and Gas & 1.70 & 1.90 & 1.87 & 1.62 & 1.81 & 1.90 & 4.43 & 2.44 & 1.90 & 1.90 & 1.90 \\
\hline 20230201 & Platform Horst/Graben-Related Oil & 1.70 & 1.89 & 1.86 & 1.42 & 2.07 & 1.85 & 4.63 & 2.49 & 1.89 & 1.89 & 1.89 \\
\hline 20230202 & Basinal Oil and Gas & 1.70 & 2.86 & 2.79 & 2.27 & 2.43 & 8.40 & 0.00 & 4.37 & 2.86 & 2.86 & 2.86 \\
\hline 20300101 & Cretaceous Reservoirs & 1.47 & 1.47 & 1.46 & 1.22 & 1.55 & 1.38 & 2.18 & 1.58 & 1.47 & 1.47 & 1.47 \\
\hline 20300102 & Tertiary Reservoirs & 1.66 & 1.66 & 1.66 & 1.89 & 2.59 & 0.71 & 2.14 & 1.83 & 1.66 & 1.66 & 1.66 \\
\hline 20300201 & Northern Qatar Arch Extension & 1.46 & 1.46 & 1.44 & 1.16 & 1.56 & 1.20 & 3.01 & 1.74 & 1.46 & 1.46 & 1.46 \\
\hline 20430101 & Southeast Sirte Clastics & 1.55 & 1.55 & 1.57 & 1.63 & 3.16 & 0.63 & 1.60 & 1.75 & 1.55 & 1.55 & 1.55 \\
\hline 20430102 & Central Sirte Carbonates & 1.67 & 1.67 & 1.66 & 1.70 & 1.35 & 1.83 & 2.49 & 1.84 & 1.67 & 1.67 & 1.67 \\
\hline 20430103 & Offshore Sirte Hypothetical & 1.70 & 2.34 & 2.32 & 1.87 & 2.41 & 3.12 & 4.21 & 2.90 & 2.34 & 2.34 & 2.34 \\
\hline 20430104 & Southeast Sirte Hypothetical & 1.70 & 2.22 & 2.19 & 1.62 & 2.31 & 3.25 & 4.65 & 2.96 & 2.22 & 2.22 & 2.22 \\
\hline 20480101 & $\begin{array}{l}\text { Bou Dabbous-Tertiary } \\
\text { Structural/Stratigraphic }\end{array}$ & 1.64 & 1.64 & 1.67 & 1.51 & 2.56 & 1.32 & 1.10 & 1.62 & 1.64 & 1.64 & 1.64 \\
\hline 20480201 & $\begin{array}{l}\text { Jurassic-Cretaceous } \\
\text { Structural/Stratigraphic }\end{array}$ & 1.70 & 1.77 & 1.74 & 1.18 & 2.52 & 1.13 & 8.94 & 3.44 & 1.77 & 1.77 & 1.77 \\
\hline 20540101 & $\begin{array}{l}\text { Tanezzuft-Oued Mya } \\
\text { Structural/Stratigraphic }\end{array}$ & 1.70 & 1.75 & 1.77 & 3.43 & 1.74 & 0.83 & 1.45 & 1.86 & 1.75 & 1.75 & 1.75 \\
\hline 20540201 & Tanezzuft-Melrhir Structural/Stratigraphic & 1.70 & 1.70 & 1.69 & 1.30 & 1.86 & 1.89 & 2.19 & 1.81 & 1.70 & 1.70 & 1.70 \\
\hline 20540301 & $\begin{array}{l}\text { Tanezzuft-Ghadames } \\
\text { Structural/Stratigraphic }\end{array}$ & 1.40 & 1.26 & 1.26 & 1.08 & 1.23 & 1.68 & 1.05 & 1.26 & 1.26 & 1.26 & 1.26 \\
\hline
\end{tabular}




\begin{tabular}{|c|c|c|c|c|c|c|c|c|c|c|c|c|}
\hline 20560101 & Tanezzuft-Illizi Structural/Stratigraphic & 1.70 & 2.00 & 2.02 & 1.56 & 2.79 & 2.34 & 1.33 & 2.00 & 2.00 & 2.00 & 2.00 \\
\hline 20580101 & $\begin{array}{l}\text { Tanezzuft-Timimoun } \\
\text { Structural/Stratigraphic }\end{array}$ & 1.40 & 1.21 & 1.18 & 1.21 & 7.17 & 0.13 & 2.06 & 2.64 & 1.21 & 1.21 & 1.17 \\
\hline 20580201 & Tanezzuft-Ahnet Structural/Stratigraphic & 1.70 & 1.97 & 1.95 & 1.01 & 3.48 & 1.50 & 43.51 & 12.37 & 1.97 & 1.97 & 1.97 \\
\hline 20580301 & Tanezzuft-Sbaa Structural/Stratigraphic & 1.70 & 1.84 & 1.80 & 1.80 & 5.32 & 0.25 & 168.11 & 43.87 & 1.84 & 1.84 & 1.84 \\
\hline 20580401 & Tanezzuft-Mouydir Structural/Stratigraphic & 1.40 & 1.00 & 3.00 & 2.75 & 3.45 & 4.59 & 0.00 & 3.60 & 1.00 & 1.00 & 3.00 \\
\hline 20580501 & Tanezzuft-Benoud Structural/Stratigraphic & 1.70 & 1.95 & 1.94 & 1.90 & 1.74 & 2.13 & 2.61 & 2.10 & 1.95 & 1.95 & 1.96 \\
\hline 20580601 & $\begin{array}{l}\text { Tanezzuft-Bechar/Abadla } \\
\text { Structural/Stratigraphic }\end{array}$ & 1.70 & 1.93 & 1.91 & 1.46 & 1.94 & 2.50 & 3.17 & 2.27 & 1.93 & 1.93 & 1.93 \\
\hline 20710101 & Gulf of Suez Block-Fault Fairway & 1.40 & 1.36 & 1.35 & 1.01 & 1.26 & 2.09 & 1.22 & 1.40 & 1.36 & 1.36 & 1.36 \\
\hline 20710102 & Gulf of Suez Qaa Plain & 1.40 & 1.00 & 2.17 & 1.71 & 2.24 & 2.93 & 3.95 & 2.71 & 1.00 & 1.00 & 2.19 \\
\hline 20710103 & Southern Gulf of Suez & 1.65 & 1.65 & 1.63 & 1.32 & 1.32 & 2.48 & 2.72 & 1.96 & 1.65 & 1.65 & 1.65 \\
\hline 20710201 & Red Sea Coastal Block Faults & 1.57 & 1.57 & 1.57 & 1.29 & 1.55 & 1.98 & 1.68 & 1.62 & 1.57 & 1.57 & 1.57 \\
\hline 20710202 & Red Sea Salt Basin & 1.70 & 3.00 & 3.00 & 2.92 & 2.93 & 3.33 & 4.42 & 3.40 & 3.00 & 3.00 & 3.00 \\
\hline 31150101 & $\begin{array}{l}\text { Upper Paleozoic/Lower Mesozoic } \\
\text { Nonmarine Coarse Clastic }\end{array}$ & 1.40 & 1.39 & 1.39 & 1.27 & 1.53 & 1.26 & 1.60 & 1.41 & 1.39 & 1.39 & 1.39 \\
\hline 31150201 & $\begin{array}{l}\text { Jurassic/Tertiary Fluvial and Lacustrine } \\
\text { Sandstone }\end{array}$ & 1.70 & 1.98 & 2.08 & 1.33 & 6.04 & 3.87 & 0.24 & 2.87 & 1.98 & 1.98 & 1.99 \\
\hline 31270101 & Tertiary Lacustrine & 1.70 & 1.78 & 1.78 & 1.67 & 1.47 & 3.41 & 1.12 & 1.92 & 1.78 & 1.78 & 1.78 \\
\hline 31270102 & Pre-Tertiary Buried Hills & 1.70 & 1.79 & 1.81 & 1.56 & 2.61 & 1.65 & 1.19 & 1.75 & 1.79 & 1.79 & 1.79 \\
\hline 31280101 & $\begin{array}{l}\text { Jurassic/Triassic Fluvial and Lacustrine } \\
\text { Sandstone }\end{array}$ & 1.70 & 1.82 & 1.80 & 0.72 & 3.50 & 1.54 & 0.00 & 1.92 & 1.82 & 1.82 & 1.82 \\
\hline 31420101 & Southeastern Fold Belt & 1.48 & 1.48 & 1.46 & 0.86 & 1.60 & 1.74 & 2.98 & 1.79 & 1.48 & 1.48 & 1.48 \\
\hline 31420102 & Northwestern Depression/Foldbelt & 1.70 & 1.72 & 1.69 & 1.62 & 2.05 & 0.83 & 10.37 & 3.72 & 1.72 & 1.72 & 1.73 \\
\hline 31420201 & Jurassic Lacustrine & 1.62 & 1.62 & 1.62 & 1.15 & 2.79 & 1.09 & 2.01 & 1.76 & 1.62 & 1.62 & 1.62 \\
\hline 31420401 & Leshan-Longnusi Paleohigh & 1.70 & 1.76 & 1.73 & 1.78 & 1.81 & 1.06 & 5.65 & 2.58 & 1.76 & 1.76 & 1.76 \\
\hline 31420402 & Lower Paleozoic of Southeastern Fold Belt & 1.70 & 2.37 & 2.35 & 1.89 & 2.44 & 3.19 & 4.29 & 2.95 & 2.37 & 2.37 & 2.37 \\
\hline 31440101 & Subtle Traps & 1.70 & 1.79 & 1.76 & 1.33 & 2.52 & 0.84 & 0.00 & 1.56 & 1.79 & 1.79 & 1.80 \\
\hline 31440102 & Anticlinal & 1.40 & 1.16 & 1.17 & 4.01 & 0.49 & 1.09 & 1.00 & 1.65 & 1.16 & 1.16 & 1.16 \\
\hline 31440201 & Structural Traps & 1.70 & 3.00 & 3.00 & 3.55 & 4.84 & 11.79 & 0.00 & 6.72 & 3.00 & 3.00 & 3.00 \\
\hline 31540101 & Tarim Basin Excluding Marginal Foldbelts & 1.70 & 2.21 & 2.18 & 1.53 & 2.40 & 3.61 & 4.05 & 2.90 & 2.21 & 2.21 & 2.21 \\
\hline 31540102 & Kuche (Northern) Foldbelt & 1.70 & 3.00 & 3.00 & 2.89 & 3.03 & 4.41 & 17.20 & 6.88 & 3.00 & 3.00 & 3.00 \\
\hline 31540103 & Southwest Foldbelt & 1.70 & 2.48 & 2.45 & 2.01 & 2.48 & 3.41 & 5.22 & 3.28 & 2.48 & 2.48 & 2.48 \\
\hline
\end{tabular}




\begin{tabular}{|c|c|c|c|c|c|c|c|c|c|c|c|c|}
\hline 37010101 & Brunei-Sabah Deltaics & 1.40 & 1.38 & 1.37 & 1.13 & 1.70 & 1.12 & 1.78 & 1.43 & 1.38 & 1.38 & 1.38 \\
\hline 37010102 & Brunei-Sabah Turbidites & 1.66 & 1.66 & 1.65 & 1.14 & 1.89 & 2.20 & 1.76 & 1.75 & 1.66 & 1.66 & 1.66 \\
\hline 37020101 & Central Luconia & 1.52 & 1.52 & 1.52 & 1.46 & 1.28 & 1.99 & 1.51 & 1.56 & 1.52 & 1.52 & 1.52 \\
\hline 37020102 & Balingian & 1.70 & 2.04 & 2.04 & 1.97 & 3.66 & 0.74 & 4.19 & 2.64 & 2.04 & 2.04 & 2.04 \\
\hline 37020201 & East Natuna & 1.70 & 2.60 & 2.57 & 2.33 & 2.45 & 3.24 & 4.57 & 3.15 & 2.60 & 2.60 & 2.60 \\
\hline 37030101 & South Malay Lacustrine & 1.62 & 1.62 & 1.61 & 1.09 & 1.68 & 2.38 & 1.91 & 1.76 & 1.62 & 1.62 & 1.62 \\
\hline 37030102 & North Malay Lacustrine & 1.70 & 3.00 & 3.00 & 2.21 & 3.69 & 6.27 & 29.56 & 10.43 & 3.00 & 3.00 & 3.00 \\
\hline 37030201 & South Malay Coaly & 1.40 & 1.38 & 1.39 & 1.29 & 4.89 & 0.34 & 1.56 & 2.02 & 1.38 & 1.38 & 1.38 \\
\hline 38080101 & Pematang/Sihapas Siliciclastics & 1.52 & 1.52 & 1.51 & 1.51 & 1.03 & 2.23 & 2.05 & 1.70 & 1.52 & 1.52 & 1.52 \\
\hline 38170101 & Kutei Basin Deltaics & 1.44 & 1.44 & 1.43 & 1.33 & 1.16 & 1.83 & 1.75 & 1.52 & 1.44 & 1.44 & 1.44 \\
\hline 38170102 & Kutei Basin Turbidites & 1.64 & 1.64 & 1.62 & 1.28 & 1.58 & 1.96 & 2.44 & 1.81 & 1.64 & 1.64 & 1.64 \\
\hline 38170103 & Kutei Basin Fold and Thrust Belt & 1.70 & 2.31 & 2.30 & 1.53 & 3.12 & 3.05 & 3.96 & 2.92 & 2.31 & 2.31 & 2.31 \\
\hline 38220101 & North Sumatra & 1.70 & 1.93 & 1.92 & 1.82 & 1.76 & 2.23 & 2.36 & 2.04 & 1.93 & 1.93 & 1.93 \\
\hline 38220102 & Mergui & 1.70 & 1.89 & 1.88 & 1.63 & 1.86 & 2.16 & 2.60 & 2.06 & 1.89 & 1.89 & 1.89 \\
\hline 38240101 & Sunda/Asri & 1.70 & 1.74 & 1.72 & 1.42 & 1.66 & 1.91 & 3.12 & 2.03 & 1.74 & 1.74 & 1.74 \\
\hline 38240201 & Ardjuna & 1.62 & 1.62 & 1.63 & 1.11 & 2.18 & 2.19 & 1.12 & 1.65 & 1.62 & 1.62 & 1.62 \\
\hline 38280101 & South Sumatra & 1.40 & 1.33 & 1.32 & 1.11 & 1.09 & 1.76 & 1.64 & 1.40 & 1.33 & 1.33 & 1.33 \\
\hline 39100101 & Barnett & 1.70 & 3.00 & 3.00 & 2.26 & 4.43 & 9.33 & 0.00 & 5.34 & 3.00 & 3.00 & 3.00 \\
\hline 39100201 & Petrel & 1.70 & 2.27 & 2.25 & 1.33 & 3.08 & 3.71 & 6.35 & 3.62 & 2.27 & 2.27 & 2.27 \\
\hline 39100202 & Vulcan Graben & 1.70 & 3.00 & 3.00 & 2.50 & 3.71 & 6.35 & 0.00 & 4.19 & 3.00 & 3.00 & 3.00 \\
\hline 39100301 & Malita & 1.70 & 1.79 & 1.81 & 1.17 & 2.38 & 3.66 & 0.81 & 2.01 & 1.79 & 1.79 & 1.79 \\
\hline 39130101 & Late Jurassic/Early Cretaceous-Mesozoic & 1.51 & 1.51 & 1.54 & 1.71 & 1.78 & 1.97 & 0.62 & 1.52 & 1.51 & 1.51 & 1.51 \\
\hline 39300101 & Gippsland & 1.70 & 1.85 & 1.87 & 1.51 & 2.90 & 1.50 & 1.51 & 1.85 & 1.85 & 1.85 & 1.85 \\
\hline 39480101 & Dingo-Mungaroo/Barrow & 1.70 & 1.84 & 1.83 & 1.57 & 1.95 & 1.94 & 2.30 & 1.94 & 1.84 & 1.84 & 1.84 \\
\hline 39480201 & Locker-Mungaroo/Barrow & 1.67 & 1.67 & 1.73 & 2.25 & 2.12 & 2.20 & 0.44 & 1.75 & 1.67 & 1.67 & 1.68 \\
\hline 40170101 & Halten Terrace-Trondelag Platform & 1.70 & 2.31 & 2.24 & 2.11 & 1.61 & 3.50 & 28.75 & 8.99 & 2.31 & 2.31 & 2.31 \\
\hline 40170102 & Mid-Norway Continental Margin & 1.50 & 1.50 & 1.49 & 1.28 & 1.44 & 1.66 & 1.94 & 1.58 & 1.50 & 1.50 & 1.50 \\
\hline 40250101 & Viking Graben & 1.43 & 1.43 & 1.41 & 1.59 & 1.07 & 1.46 & 2.13 & 1.56 & 1.43 & 1.43 & 1.43 \\
\hline 40250102 & Moray Firth & 1.62 & 1.62 & 1.60 & 1.33 & 1.82 & 1.22 & 3.86 & 2.06 & 1.62 & 1.62 & 1.62 \\
\hline 40250103 & Central Graben & 1.67 & 1.67 & 1.65 & 1.26 & 1.76 & 1.79 & 2.70 & 1.88 & 1.67 & 1.67 & 1.67 \\
\hline 40360101 & Southern Permian Basin-U.K. Onshore & 1.70 & 2.60 & 2.58 & 7.91 & 0.00 & 0.00 & 0.00 & 3.95 & 2.60 & 2.60 & 2.62 \\
\hline
\end{tabular}




\begin{tabular}{|c|c|c|c|c|c|c|c|c|c|c|c|c|}
\hline 40360102 & Southern Permian Basin-Europe Onshore & 1.40 & 1.23 & 1.21 & 1.06 & 0.98 & 1.28 & 2.24 & 1.39 & 1.23 & 1.23 & 1.23 \\
\hline 40360103 & Southern Permian Basin-Offshore & 1.70 & 1.73 & 1.71 & 1.45 & 1.58 & 2.17 & 2.39 & 1.90 & 1.73 & 1.73 & 1.73 \\
\hline 40470101 & Foreland Basin & 1.70 & 1.73 & 1.74 & 2.07 & 1.56 & 1.62 & 1.63 & 1.72 & 1.73 & 1.73 & 1.73 \\
\hline 40470201 & Deformed Belt & 1.70 & 1.85 & 1.79 & 2.16 & 1.00 & 2.34 & 7.06 & 3.14 & 1.85 & 1.85 & 1.85 \\
\hline 40470301 & Paleozoic Reservoirs & 1.70 & 3.00 & 3.00 & 2.69 & 4.01 & 7.03 & 0.00 & 4.58 & 3.00 & 3.00 & 3.00 \\
\hline 40480101 & Greater Hungarian Plain Basins & 1.70 & 1.92 & 1.91 & 1.83 & 1.54 & 3.17 & 1.68 & 2.05 & 1.92 & 1.92 & 1.92 \\
\hline 40480201 & Zala-Drava-Sava Basins & 1.70 & 1.91 & 1.93 & 1.65 & 3.35 & 1.07 & 2.11 & 2.04 & 1.91 & 1.91 & 1.91 \\
\hline 40480301 & Danube Basin & 1.55 & 1.55 & 1.62 & 2.25 & 2.59 & 4.09 & 0.13 & 2.27 & 1.55 & 1.55 & 1.55 \\
\hline 40480401 & Transcarpathian Basin & 1.70 & 3.00 & 3.00 & 1228.79 & 0.00 & 0.00 & 0.00 & 1228.79 & 3.00 & 3.00 & 3.00 \\
\hline 40480601 & Hungarian Paleogene Basin & 1.70 & 2.77 & 2.76 & 1.60 & 5.10 & 4.94 & 13.44 & 6.27 & 2.77 & 2.77 & 2.77 \\
\hline 40570101 & Transylvanian Neogene Suprasalt Gas & 1.40 & 1.31 & 1.28 & 1.16 & 1.11 & 1.04 & 3.83 & 1.79 & 1.31 & 1.31 & 1.31 \\
\hline 40600101 & Neogene Flysch Gas & 1.60 & 1.60 & 1.60 & 1.09 & 1.82 & 1.94 & 2.06 & 1.73 & 1.60 & 1.60 & 1.60 \\
\hline 40600201 & Thermal Triassic & 1.40 & 1.19 & 1.16 & 0.80 & 0.89 & 1.37 & 2.82 & 1.47 & 1.19 & 1.19 & 1.19 \\
\hline 40610101 & Moesian Platform & 1.49 & 1.49 & 1.48 & 1.50 & 1.28 & 1.50 & 2.05 & 1.58 & 1.49 & 1.49 & 1.49 \\
\hline 40610201 & Romania Flysch Zone & 1.70 & 2.11 & 2.07 & 2.10 & 1.39 & 3.26 & 5.22 & 2.99 & 2.11 & 2.11 & 2.12 \\
\hline 40610202 & Romania Ploiesti Zone & 1.40 & 1.26 & 1.25 & 0.92 & 1.35 & 1.40 & 1.44 & 1.28 & 1.26 & 1.26 & 1.26 \\
\hline 40680101 & Subsalt & 1.67 & 1.67 & 1.66 & 1.32 & 1.62 & 2.01 & 2.52 & 1.87 & 1.67 & 1.67 & 1.68 \\
\hline 52000101 & Northeast Greenland Shelf Rift Systems & 1.60 & 1.60 & 1.59 & 1.34 & 1.55 & 1.79 & 2.07 & 1.69 & 1.60 & 1.60 & 1.60 \\
\hline 52150101 & Jeanne d'Arc & 1.70 & 1.83 & 1.83 & 1.91 & 3.30 & 0.63 & 3.31 & 2.29 & 1.83 & 1.83 & 1.83 \\
\hline 52430101 & Keg River Gas & 1.70 & 1.72 & 1.71 & 1.28 & 1.68 & 2.71 & 1.75 & 1.86 & 1.72 & 1.72 & 1.72 \\
\hline 52430102 & Keg River Oil and Gas & 1.70 & 1.91 & 1.89 & 2.31 & 1.35 & 2.27 & 2.00 & 1.98 & 1.91 & 1.91 & 1.91 \\
\hline 52430201 & Leduc Gas & 1.70 & 1.86 & 1.83 & 1.79 & 1.75 & 1.57 & 3.89 & 2.25 & 1.86 & 1.86 & 1.86 \\
\hline 52430202 & Leduc Oil and Gas & 1.51 & 1.51 & 1.51 & 1.37 & 1.58 & 1.48 & 1.73 & 1.54 & 1.51 & 1.51 & 1.51 \\
\hline 52430301 & Exshaw-Rundle Gas & 1.62 & 1.62 & 1.61 & 1.00 & 1.79 & 2.18 & 2.43 & 1.85 & 1.62 & 1.62 & 1.62 \\
\hline 52430302 & Exshaw-Rundle Oil and Gas & 1.70 & 1.91 & 1.90 & 1.76 & 1.98 & 1.69 & 2.93 & 2.09 & 1.91 & 1.91 & 1.91 \\
\hline 52430401 & Combined Triassic/Jurassic Gas & 1.70 & 1.87 & 1.88 & 1.26 & 3.01 & 1.77 & 1.85 & 1.97 & 1.87 & 1.87 & 1.87 \\
\hline 52430402 & Combined Triassic/Jurassic Oil and Gas & 1.70 & 2.03 & 2.03 & 2.06 & 2.31 & 1.49 & 2.54 & 2.10 & 2.03 & 2.03 & 2.03 \\
\hline 52430501 & Manville Gas & 1.70 & 2.34 & 2.33 & 2.14 & 2.36 & 2.84 & 2.24 & 2.40 & 2.34 & 2.34 & 2.34 \\
\hline 52430601 & Second White Specks-Cardium Gas & 1.70 & 2.76 & 2.67 & 3.79 & 1.51 & 2.17 & 0.00 & 2.49 & 2.76 & 2.76 & 2.76 \\
\hline 52430602 & $\begin{array}{l}\text { Second White Specks-Cardium Oil and } \\
\text { Gas }\end{array}$ & 1.70 & 1.95 & 1.97 & 1.96 & 2.22 & 2.04 & 1.27 & 1.87 & 1.95 & 1.95 & 1.95 \\
\hline
\end{tabular}




\begin{tabular}{|c|c|c|c|c|c|c|c|c|c|c|c|c|}
\hline 52440101 & Yeoman Oil & 1.70 & 3.00 & 3.00 & 3.61 & 5.68 & 15.25 & 0.00 & 8.18 & 3.00 & 3.00 & 3.00 \\
\hline 52440201 & Brightholme Oil & 1.70 & 3.00 & 3.00 & 1.47 & 75.14 & 0.00 & 0.00 & 38.31 & 3.00 & 3.00 & 3.00 \\
\hline 52440301 & Bakken Sandstone & 1.70 & 3.00 & 3.00 & 1.84 & 23.50 & 0.00 & 0.00 & 12.67 & 3.00 & 3.00 & 3.00 \\
\hline 52440401 & Lodgepole Oil & 1.40 & 1.31 & 1.32 & 1.22 & 1.29 & 2.26 & 0.67 & 1.36 & 1.31 & 1.31 & 1.31 \\
\hline 53050101 & El Abra-Like Reef and Backreef Limestone & 1.70 & 1.70 & 1.70 & 2.59 & 1.01 & 2.09 & 1.53 & 1.80 & 1.70 & 1.70 & 1.70 \\
\hline 53050102 & $\begin{array}{l}\text { Tamabra-Like Debris-Flow-Breccia } \\
\text { Limestone Overlying Evaporites }\end{array}$ & 1.40 & 1.38 & 1.38 & 1.13 & 1.35 & 1.86 & 1.24 & 1.39 & 1.38 & 1.38 & 1.38 \\
\hline 53050103 & $\begin{array}{l}\text { Tamabra-Like Debris-Flow-Breccia } \\
\text { Limestone and Overlying Strata }\end{array}$ & 1.70 & 1.88 & 1.85 & 1.73 & 1.39 & 3.09 & 2.46 & 2.17 & 1.88 & 1.88 & 1.88 \\
\hline 53050104 & $\begin{array}{l}\text { Tamabra-Like Debris-Flow-Breccia } \\
\text { Limestone of the Golden Lane }\end{array}$ & 1.40 & 1.20 & 1.18 & 0.55 & 1.40 & 1.43 & 1.72 & 1.27 & 1.20 & 1.20 & 1.20 \\
\hline 53050105 & $\begin{array}{l}\text { Tamaulipas-Like Basinal Limestone and } \\
\text { Tertiary Strata Without Underlying } \\
\text { Evaporites }\end{array}$ & 1.40 & 1.01 & 1.04 & 1.94 & 1.31 & 0.51 & 1.03 & 1.20 & 1.01 & 1.01 & 1.01 \\
\hline 53050106 & $\begin{array}{l}\text { Tamaulipas-Like Basinal Limestone and } \\
\text { Tertiary Strata Overlying Evaporites }\end{array}$ & 1.70 & 2.10 & 2.09 & 1.28 & 2.63 & 3.81 & 2.73 & 2.61 & 2.10 & 2.10 & 2.10 \\
\hline 53050107 & $\begin{array}{l}\text { Tamabra-Like Debris-Flow-Breccia } \\
\text { Limestone North of Campeche }\end{array}$ & 1.70 & 1.82 & 1.81 & 1.51 & 1.78 & 2.14 & 2.61 & 2.01 & 1.82 & 1.82 & 1.82 \\
\hline 60210101 & Late Cretaceous-Tertiary Turbidites & 1.44 & 1.44 & 1.43 & 1.21 & 1.38 & 1.60 & 1.86 & 1.51 & 1.44 & 1.44 & 1.44 \\
\hline 60210102 & Cretaceous Carbonates & 1.70 & 1.78 & 1.77 & 1.45 & 1.75 & 2.11 & 2.57 & 1.97 & 1.78 & 1.78 & 1.78 \\
\hline 60210103 & $\begin{array}{l}\text { Late Cretaceous-Tertiary Nearshore } \\
\text { Sandstones }\end{array}$ & 1.70 & 1.83 & 1.81 & 1.49 & 1.79 & 2.17 & 2.66 & 2.03 & 1.83 & 1.83 & 1.83 \\
\hline 60220101 & Amazon Delta and Submarine Fan & 1.70 & 2.10 & 2.07 & 1.76 & 1.82 & 3.21 & 3.39 & 2.54 & 2.10 & 2.10 & 2.10 \\
\hline 60290101 & Western Pre-Aptian Reservoirs & 1.40 & 1.24 & 1.26 & 1.68 & 1.26 & 1.74 & 0.53 & 1.30 & 1.24 & 1.24 & 1.24 \\
\hline 60290102 & $\begin{array}{l}\text { Late Cretaceous-Tertiary Deep-Water } \\
\text { Sandstones }\end{array}$ & 1.40 & 1.37 & 1.36 & 1.01 & 1.47 & 1.30 & 2.32 & 1.52 & 1.37 & 1.37 & 1.37 \\
\hline 60340101 & Espirito Santo Shelf & 1.70 & 1.88 & 1.88 & 0.57 & 7.20 & 1.03 & 0.00 & 2.93 & 1.88 & 1.88 & 1.88 \\
\hline 60340102 & $\begin{array}{l}\text { Late Cretaceous-Tertiary Slide Blocks and } \\
\text { Turbidites }\end{array}$ & 1.45 & 1.45 & 1.44 & 1.20 & 1.39 & 1.62 & 1.91 & 1.53 & 1.45 & 1.45 & 1.45 \\
\hline 60340103 & Abrolhos Sub-Volcanic Structures & 1.70 & 1.75 & 1.74 & 1.52 & 1.70 & 1.95 & 2.27 & 1.86 & 1.75 & 1.75 & 1.75 \\
\hline 60350101 & Late Cretaceous-Tertiary Turbidites & 1.40 & 1.30 & 1.28 & 1.08 & 1.05 & 1.44 & 2.28 & 1.46 & 1.30 & 1.30 & 1.30 \\
\hline 60350102 & Cretaceous Carbonates & 1.56 & 1.56 & 1.58 & 1.08 & 1.97 & 3.52 & 0.58 & 1.79 & 1.56 & 1.56 & 1.56 \\
\hline 60350103 & Salt Dome Province Tertiary Sandstones & 1.59 & 1.59 & 1.58 & 1.28 & 1.53 & 1.86 & 2.26 & 1.73 & 1.59 & 1.59 & 1.60 \\
\hline 60360101 & Santos Shelf & 1.63 & 1.63 & 1.62 & 1.46 & 1.53 & 1.80 & 2.12 & 1.73 & 1.63 & 1.63 & 1.63 \\
\hline
\end{tabular}


60360102 Salt-Structured Deep-Water Sandstones 60370101 Pelotas Platform and Basin

60410101 Hollin-Napo

60410201 Ene

60450101 Sub-Andean Fold and Thrust Belt

60450102 Foreland Basins

60450103 Foreland Central Chaco High

60550101 Neuquen Extensional Structures

60550102 Neuquen Foothills Structure

60550103 Dorsal de Neuquen Structure

60580101 San Jorge Extensional Structures

60580102 San Bernardo Fold Belt Structures

60590101 Magallanes Extensional Structures

60590102 Andean Fold Belt Structures

60600101 North Falklands Basin

60600201 South Falklands Basin

60630101 Malvinas Extensional Structures

60810101 Cretaceous-Paleogene Basin

60830101 Neogene Pull-Apart Basin

60830201 Cretaceous-Paleogene Santa Elena Block 60900101 Northern

60900102 Southern

60900103 Eastern

60900104 La Luna and Older

60960101 Central

60960102 Peripheral

60980101 East Venezuela Fold and Thrust Belt

60980102 Guarico Sub-Basin

60980103 Maturin Sub-Basin

60980201 Trinidad Basins

60980202 Orinoco Delta and Offshore

\begin{tabular}{||l|l|l|l|l|l|l|l|l|l|l|}
\hline 1.70 & 1.76 & 1.75 & 1.38 & 1.73 & 2.16 & 2.73 & 2.00 & 1.76 & 1.76 & 1.77 \\
\hline 1.70 & 1.95 & 1.93 & 1.55 & 1.94 & 2.44 & 3.06 & 2.25 & 1.95 & 1.95 & 1.95 \\
\hline 1.40 & 1.24 & 1.23 & 1.05 & 1.27 & 1.18 & 1.58 & 1.27 & 1.24 & 1.24 & 1.24 \\
\hline 1.70 & 2.75 & 2.71 & 1.98 & 3.04 & 5.26 & 13.18 & 5.87 & 2.75 & 2.75 & 2.75 \\
\hline 1.40 & 1.35 & 1.34 & 1.67 & 1.02 & 1.48 & 1.40 & 1.39 & 1.35 & 1.35 & 1.35 \\
\hline 1.66 & 1.66 & 1.65 & 1.25 & 1.74 & 1.93 & 2.32 & 1.81 & 1.66 & 1.66 & 1.66 \\
\hline 1.68 & 1.68 & 1.67 & 1.37 & 1.64 & 1.96 & 2.35 & 1.83 & 1.68 & 1.68 & 1.68 \\
\hline 1.63 & 1.63 & 1.63 & 1.23 & 1.49 & 2.78 & 1.58 & 1.77 & 1.63 & 1.63 & 1.63 \\
\hline 1.52 & 1.52 & 1.50 & 1.13 & 1.40 & 1.85 & 2.68 & 1.76 & 1.52 & 1.52 & 1.52 \\
\hline 1.70 & 1.84 & 1.86 & 3.31 & 0.87 & 5.13 & 0.53 & 2.46 & 1.84 & 1.84 & 1.84 \\
\hline 1.40 & 1.22 & 1.23 & 1.20 & 1.65 & 0.89 & 1.24 & 1.25 & 1.22 & 1.22 & 1.22 \\
\hline 1.70 & 1.76 & 1.78 & 2.32 & 2.80 & 0.73 & 1.63 & 1.87 & 1.76 & 1.76 & 1.76 \\
\hline 1.59 & 1.59 & 1.60 & 1.36 & 1.93 & 1.58 & 1.47 & 1.59 & 1.59 & 1.59 & 1.59 \\
\hline 1.70 & 2.28 & 2.26 & 1.85 & 2.33 & 2.95 & 3.78 & 2.73 & 2.28 & 2.28 & 2.28 \\
\hline 1.70 & 1.83 & 1.82 & 1.63 & 1.80 & 2.02 & 2.30 & 1.94 & 1.83 & 1.83 & 1.83 \\
\hline 1.70 & 1.83 & 1.82 & 1.63 & 1.80 & 2.02 & 2.30 & 1.94 & 1.83 & 1.83 & 1.83 \\
\hline 1.70 & 1.98 & 1.96 & 1.63 & 1.96 & 2.39 & 2.96 & 2.24 & 1.98 & 1.98 & 1.98 \\
\hline 1.44 & 1.44 & 1.43 & 0.91 & 1.69 & 1.59 & 2.06 & 1.56 & 1.44 & 1.44 & 1.44 \\
\hline 1.45 & 1.45 & 1.46 & 1.13 & 1.47 & 3.12 & 0.67 & 1.60 & 1.45 & 1.45 & 1.45 \\
\hline 1.62 & 1.62 & 1.65 & 1.84 & 1.83 & 2.20 & 0.63 & 1.63 & 1.62 & 1.62 & 1.62 \\
\hline 1.40 & 1.35 & 1.38 & 1.43 & 1.82 & 2.25 & 0.39 & 1.47 & 1.35 & 1.35 & 1.35 \\
\hline 1.40 & 1.17 & 1.18 & 1.01 & 1.70 & 0.91 & 1.12 & 1.19 & 1.17 & 1.17 & 1.17 \\
\hline 1.70 & 2.22 & 2.21 & 1.28 & 3.37 & 3.16 & 4.14 & 2.99 & 2.22 & 2.22 & 2.22 \\
\hline 1.70 & 2.82 & 2.79 & 2.38 & 2.83 & 3.88 & 6.70 & 3.95 & 2.82 & 2.82 & 2.83 \\
\hline 1.40 & 1.19 & 1.18 & 1.01 & 0.80 & 1.88 & 1.41 & 1.28 & 1.19 & 1.19 & 1.19 \\
\hline 1.40 & 1.28 & 1.28 & 1.09 & 1.40 & 1.35 & 1.26 & 1.27 & 1.28 & 1.28 & 1.28 \\
\hline 1.40 & 1.18 & 1.18 & 1.10 & 1.23 & 1.31 & 1.04 & 1.17 & 1.18 & 1.18 & 1.18 \\
\hline 1.40 & 1.37 & 1.36 & 1.19 & 1.17 & 1.70 & 1.66 & 1.43 & 1.37 & 1.37 & 1.37 \\
\hline 1.40 & 1.21 & 1.22 & 1.20 & 1.23 & 1.48 & 0.90 & 1.20 & 1.21 & 1.21 & 1.21 \\
\hline 1.43 & 1.43 & 1.42 & 1.82 & 1.02 & 1.78 & 1.28 & 1.47 & 1.43 & 1.43 & 1.43 \\
\hline 1.62 & 1.62 & 1.61 & 1.42 & 1.57 & 1.78 & 2.05 & 1.71 & 1.62 & 1.62 & 1.62 \\
\hline
\end{tabular}




\begin{tabular}{|c|c|c|c|c|c|c|c|c|c|c|c|c|}
\hline 60990101 & Main Maracaibo Basin & 1.40 & 1.38 & 1.37 & 1.00 & 1.45 & 1.50 & 1.95 & 1.47 & 1.38 & 1.38 & 1.38 \\
\hline 60990102 & Southwest Maracaibo Basin Fold Belt & 1.41 & 1.41 & 1.40 & 1.28 & 1.12 & 1.69 & 2.13 & 1.56 & 1.41 & 1.41 & 1.41 \\
\hline 61030101 & Carupano Basin Gas & 1.40 & 1.39 & 1.40 & 1.38 & 1.61 & 1.18 & 1.42 & 1.40 & 1.39 & 1.39 & 1.39 \\
\hline 61070101 & Inner Forearc Deformation Belt & 1.70 & 1.72 & 1.71 & 1.38 & 1.68 & 2.05 & 2.52 & 1.90 & 1.72 & 1.72 & 1.72 \\
\hline 61170101 & North Cuba Fold and Thrust Belt & 1.64 & 1.64 & 1.63 & 1.61 & 1.47 & 1.87 & 1.73 & 1.67 & 1.64 & 1.64 & 1.64 \\
\hline 70130101 & Coastal Plain and Offshore & 1.52 & 1.52 & 1.51 & 1.09 & 1.38 & 2.26 & 2.01 & 1.68 & 1.52 & 1.52 & 1.52 \\
\hline 71830101 & Coastal Plain and Offshore & 1.70 & 1.71 & 1.68 & 1.37 & 1.49 & 2.04 & 3.78 & 2.17 & 1.71 & 1.71 & 1.71 \\
\hline 71920101 & Agbada Reservoirs & 1.40 & 1.39 & 1.38 & 1.19 & 1.34 & 1.37 & 2.10 & 1.50 & 1.39 & 1.39 & 1.39 \\
\hline 71920102 & Akata Reservoirs & 1.51 & 1.51 & 1.50 & 1.23 & 1.46 & 1.72 & 2.03 & 1.61 & 1.51 & 1.51 & 1.51 \\
\hline 72030101 & Gabon Subsalt & 1.68 & 1.68 & 1.64 & 2.17 & 1.12 & 1.09 & 15.96 & 5.09 & 1.68 & 1.68 & 1.69 \\
\hline 72030201 & Gabon Suprasalt & 1.61 & 1.61 & 1.59 & 1.53 & 1.37 & 1.45 & 3.79 & 2.04 & 1.61 & 1.61 & 1.61 \\
\hline 72030301 & $\begin{array}{l}\text { Central Congo Delta and Carbonate } \\
\text { Platform }\end{array}$ & 1.40 & 1.32 & 1.32 & 1.08 & 1.51 & 1.31 & 1.39 & 1.32 & 1.32 & 1.32 & 1.32 \\
\hline 72030302 & Central Congo Turbidites & 1.70 & 2.09 & 2.06 & 1.64 & 1.86 & 3.71 & 2.83 & 2.51 & 2.09 & 2.09 & 2.09 \\
\hline 72030401 & Cuanza-Namibe & 1.40 & 1.37 & 1.37 & 1.34 & 1.71 & 1.09 & 1.36 & 1.37 & 1.37 & 1.37 & 1.37 \\
\hline 73030101 & Offshore & 1.44 & 1.44 & 1.45 & 1.53 & 1.10 & 3.68 & 0.55 & 1.72 & 1.44 & 1.44 & 1.44 \\
\hline 80260101 & Kohat-Potwar Intrathrust Basin & 1.70 & 1.83 & 1.77 & 1.22 & 0.87 & 52.85 & 0.00 & 18.31 & 1.83 & 1.83 & 1.84 \\
\hline 80340101 & Sylhet-Kopili/Barail-Tipam Composite & 1.53 & 1.53 & 1.56 & 1.25 & 3.37 & 1.11 & 0.83 & 1.64 & 1.53 & 1.53 & 1.53 \\
\hline 80420101 & Greater Indus Foreland and Foldbelt & 1.57 & 1.57 & 1.57 & 1.18 & 1.90 & 1.69 & 1.61 & 1.60 & 1.57 & 1.57 & 1.57 \\
\hline 80420102 & Indus Fan & 1.70 & 2.08 & 2.06 & 1.79 & 2.05 & 2.43 & 2.92 & 2.30 & 2.08 & 2.08 & 2.08 \\
\hline 80430101 & Eocene-Miocene Bombay Shelf & 1.70 & 1.72 & 1.71 & 1.22 & 1.95 & 2.34 & 1.73 & 1.81 & 1.72 & 1.72 & 1.72 \\
\hline 80430102 & Eocene-Miocene Cambay Deltaic & 1.60 & 1.60 & 1.60 & 1.37 & 2.00 & 1.35 & 1.87 & 1.65 & 1.60 & 1.60 & 1.60 \\
\hline 80470201 & Western Shelf and Slope & 1.70 & 1.74 & 1.73 & 1.57 & 1.71 & 1.87 & 2.08 & 1.81 & 1.74 & 1.74 & 1.74 \\
\hline 80470301 & Central Basin & 1.46 & 1.46 & 1.46 & 1.26 & 1.40 & 1.60 & 1.87 & 1.53 & 1.46 & 1.46 & 1.46 \\
\hline 80470302 & Eastern Fold Belt & 1.40 & 1.38 & 1.38 & 1.13 & 1.17 & 2.25 & 1.18 & 1.44 & 1.38 & 1.38 & 1.38 \\
\hline 80480101 & Central Burma Basin & 1.66 & 1.66 & 1.64 & 1.17 & 1.62 & 2.02 & 3.33 & 2.03 & 1.66 & 1.66 & 1.66 \\
\hline 80480102 & Irrawaddy-Andaman & 1.40 & 1.35 & 1.34 & 1.21 & 1.30 & 1.21 & 2.09 & 1.45 & 1.35 & 1.35 & 1.35 \\
\hline
\end{tabular}


The base case $r$ given in table 7 is that calculated by algorithms as close as possible to those used in 1995. The differences between the 1995 methodology and that used in the base case for the analog database were that the calculations were done at an assessment unit scale rather than at a province scale (table 6 , assumption 13) and the distinction that the modal class was not always class 6 (because of use of the lognormal distribution).

Assumption 2 restricts $r$ to a range from 1.4 to 1.7. Tests were run allowing the broader range of 1.0 to 3.0; table 7 refers to this as the extended base case. Even more extreme values of $\mathrm{r}$ would have resulted if these limits were further extended. The extended base case was the case used for all the other sensitivity tests. That is, the other sensitivity tests used r's limited to the range from 1.0 to 3.0 .

Assumption 3 refers to the use of the original 1995 least squares method to calculate $r$. To examine the sensitivity of assumption 3 , a maximum likelihood measure was used to choose r. The maximum likelihood calculation was based on the fit to a multinomial distribution ("multinomial r" in table 7); the results (table 7) show no significant change in $r$.

An additional examination of assumption 3 was done with calculations of $r$ based on individual ratios of counts in pairs of classes above the mean. The column in table 7 entitled "ratio 1 / 2" gives the ratio of the count of the class one step above the modal class to that of the count of that class two steps above the modal class. The columns "ratio $2 / 3$," "ratio $3 / 4$," and "ratio 4 / 5" are defined similarly. The "mean ratio" is the mean of these four values. As expected, "ratio $1 / 2$ " is closest to the extended base case value. Because of small numbers of fields in some of the higher classes, "ratio 4 / 5" can have extreme values, which affects the "mean ratio" also.

The columns " 1.4 mean" and " 1.38 mean" in table 7 examine the sensitivity of assumption 4 of table 6 . They show minimal changes from the extended base case.

The "no $<1$ constraint" column in table 7 relates to assumption 5 of table 6 . In the original 1995 methodology, any bins with a count less than 1 were not used in the calculations. By dropping this constraint, several assessment units with low field counts showed changes in $r$.

\section{Unresolved Issues}

The main unresolved issue for the methodology used in constructing our analog database is the form of field-size population distributions. An extensive literature argues that the underlying distribution of field sizes is either lognormal (Kaufman, 1993; Rose, 1994) or Pareto (Schuenemeyer and Drew, 1983; Houghton, 1988). Attanasi and Charpentier (2002) studied the effects of distribution type on the 1995 U.S. National Oil and Gas Assessment distributions. One alternative to the Pareto procedure used in our database may be to fit the small-field end of the distribution using robust regression estimation procedures. 
Another important unresolved issue is the constraining of $r$ to values of 1.4 to 1.7. In the original 58 assessed provinces of the 1995 National Assessment, 16 values were calculated as 1.4 and 29 values as 1.7 (table 8). Only 13 provinces had values of $r$ between 1.4 and 1.7. Thus, the constraint significantly affected the calculation of $r$.

Table 8. Calculated $r$ values by province from the 1995 USGS National Assessment (Gautier and others, 1995).

\begin{tabular}{|c|c|c|}
\hline \multicolumn{2}{|r|}{ Province * } & \multirow{2}{*}{$\begin{array}{c}\text { Calculated r } \\
1.40\end{array}$} \\
\hline 1 & Northern Alaska & \\
\hline 2 & Central Alaska & 1.58 \\
\hline 3 & Southern Alaska & 1.40 \\
\hline 4 & Western Oregon-Washington & 1.70 \\
\hline 5 & Eastern Oregon-Washington & 1.70 \\
\hline 7 & Northern Coastal & 1.70 \\
\hline 8 & Sonoma-Livermore Basin & 1.70 \\
\hline 9 & Sacramento Basin & 1.55 \\
\hline 10 & San Joaquin Basin & 1.40 \\
\hline 11 & Central Coastal & 1.70 \\
\hline 12 & Santa Maria Basin & 1.40 \\
\hline 13 & Ventura Basin & 1.40 \\
\hline 14 & Los Angeles Basin & 1.40 \\
\hline 17 & Idaho-Snake River Downwarp & 1.70 \\
\hline 18 & Western Great Basin & 1.68 \\
\hline 19 & Eastern Great Basin & 1.70 \\
\hline 20 & Uinta-Piceance Basin & 1.70 \\
\hline 21 & Paradox Basin & 1.70 \\
\hline 22 & San Juan Basin & 1.52 \\
\hline 23 & Albuquerque-Santa Fe Rift & 1.70 \\
\hline 24 & Northern Arizona & 1.70 \\
\hline 25 & Southern Arizona-South West New Mexico & 1.40 \\
\hline 27 & Montana Thrust Belt & 1.41 \\
\hline 28 & Central Montana & 1.70 \\
\hline 29 & Southwest Montana & 1.70 \\
\hline 31 & Williston Basin & 1.70 \\
\hline 33 & Powder River Basin & 1.69 \\
\hline 34 & Big Horn Basin & 1.40 \\
\hline 35 & Wind River Basin & 1.40 \\
\hline 36 & Wyoming Thrust Belt & 1.40 \\
\hline 37 & Southwest Wyoming & 1.40 \\
\hline 38 & Park Basins & 1.70 \\
\hline 39 & Denver Basin & 1.70 \\
\hline 40 & Las Animas Arch & 1.40 \\
\hline 41 & Raton Basin-Sierra Grande Uplift & 1.70 \\
\hline 43 & Palo Duro Basin & 1.70 \\
\hline 44 & Permian Basin & 1.42 \\
\hline 45 & Bend Arch-Fort Worth Basin & 1.70 \\
\hline
\end{tabular}




\begin{tabular}{lll}
46 & Marathon Thrust Belt & 1.70 \\
47 & Western Gulf & 1.40 \\
49 & Louisiana-Mississippi Salt Basins & 1.58 \\
50 & Florida Peninsula & 1.40 \\
51 & Superior & 1.70 \\
53 & Cambridge Arch-Central Kansas Uplift & 1.70 \\
55 & Nemaha Uplift & 1.70 \\
56 & Forest City Basin & 1.70 \\
58 & Anadarko Basin & 1.51 \\
59 & Sedgwick Basin & 1.57 \\
60 & Cherokee Basin & 1.46 \\
61 & Southern Oklahoma & 1.49 \\
62 & Arkoma Basin & 1.40 \\
63 & Michigan Basin & 1.70 \\
64 & Illinois Basin & 1.65 \\
65 & Black Warrior Basin & 1.70 \\
66 & Cincinnati Arch & 1.70 \\
67 & Appalachian Basin & 1.70 \\
68 & Blue Ridge Thrust Belt & 1.70 \\
69 & Piedmont & 1.40 \\
\hline
\end{tabular}

* Only those provinces with small-field assessments are included in this table.

The present USGS assessment methodology uses a truncated shifted lognormal distribution to approximate the numbers and sizes of fields larger than some minimum field size. If a small-field extrapolation is applied to this distribution, additional fields are added to the size class or classes just above the minimum field size. This leads to two different numbers of fields larger than the minimum: the number of fields larger than size X (as originally assessed) versus the number of fields larger than size X (with small field extrapolation). The median and mean field sizes above the minimum field size are similarly affected. Additional methodological work is needed to connect the values in the analog database (which include the small-field correction) with the values needed for the assessment input form, which not only do not include the smallfield correction but also are for the undiscovered portion of the field population.

\section{Appendix 2. Database Files}

For those users with Microsoft Excel, the following workbook includes the complete analog database as well as several additional tools to aid use of the database.

\section{WorldAnalogs.xls}

LINK TO DOWNLOAD FILE HERE 
For those users without Microsoft Excel, the database is distributed among eight files. Each file is tab-delimited to make it easy to import into the spreadsheet program of your choice. The additional tools are not included. The eight files are:

WA_geology.tab the classification variables

WA_oil.tab the utility variables for oil fields

WA_gas.tab the utility variables for gas fields

WA_BOE.tab the utility variables for all fields (in BOE)

WA_oilbins.tab the counts of discovered and undiscovered oil fields by size class

WA_gasbins.tab the counts of discovered and undiscovered gas fields by size class

WA_BOEbins.tab the counts of discovered and undiscovered all fields (in BOE) by size class

WA_ancillary.tab the utility variables for ancillary data

LINKS TO DOWNLOAD FILES HERE 